\title{
The value relevance of accounting information including intangibles A comparative applied study of Companies Listed in the Egyptian stock market based on ownership structure Dr. Maha Mohamed Ramadan
}

\begin{abstract}
This study aims to examine the value relevance of accounting information for companies listed in the Egyptian stock market and the incremental increase in the explanatory power of accounting numbers resulting from the recognition of intangible assets and R\&D expenses. In addition, the study aims to investigate how the firm's ownership structure as being concentrated or non-concentrated can affect the value relevance of accounting information including intangibles. A sample of 375 firms listed in the Egyptian stock market during the period from 2013-2016 is used to test the research model which is based on the original Ohlson model by using a multivariate regression analysis. Results agreed with previous studies concerning the value relevance of accounting information especially earnings and provided evidence for the presence of a positive significant effect between earnings' figures and the market value of firm's equity and contradicted previous studies with respect to the significance of intangibles finding that each of total intangible assets and $\mathrm{R} \& \mathrm{D}$ expenses did not have a significant effect on market prices and did not improve the value relevance of the model. Two proxies were used to classify the sampled data into dispersed and concentrated structures which are the percentage of shares owned by the largest investor and the block holders' percentage of ownership are used to investigate the value relevance of accounting information and the associated value relevance of intangibles under each ownership structure. The study provided a strong evidence for the existence of an inverse association between the percentage of ownership concentration and value relevance of accounting information; i.e. the less concentrated the firm's ownership structure, the higher the value relevance of accounting information represented by the positive significance of earnings and book value of equity. In contrast, high concentrated ownership structures showed lower levels of value relevance with earnings numbers becoming more significant. Intangibles did not show any significance or value relevance in either of the two ownership structures.
\end{abstract}

Key words: value-relevance, intangible assets, $R \& D$ expenses, ownership concentration. 


\section{مدي ملاءمة المعلومات المحاسبية متضمنة العناصر غير الملموسة لأغراض قياس القيمة \\ دراسة تطبيقية مقارنة علي الثركات المسجلة في البورصة المصرية علي أساس هيكل الملكية

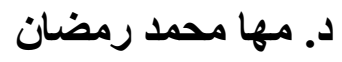

ملخص

تستهدف الدراسة إلي اختبار مدي ملاعمة المعلومات المحاسبية لأغر اض قياس القيمة للثركات المسجلة في

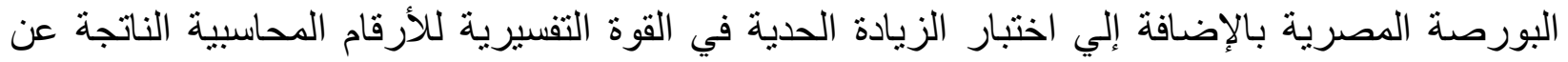

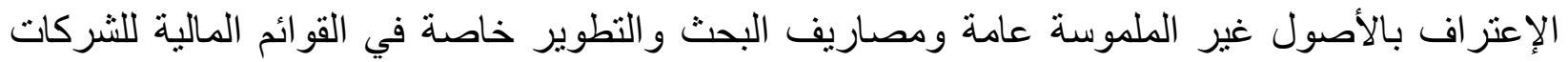

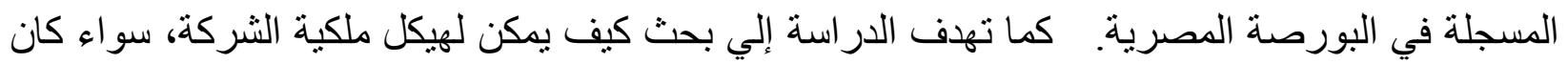

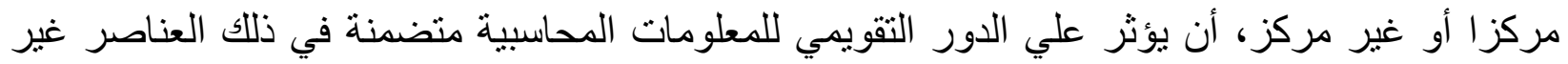

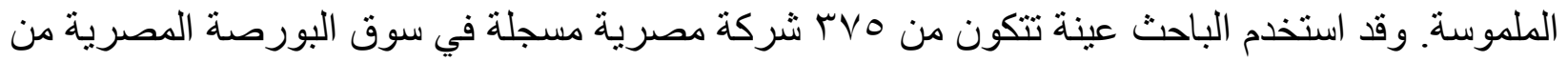

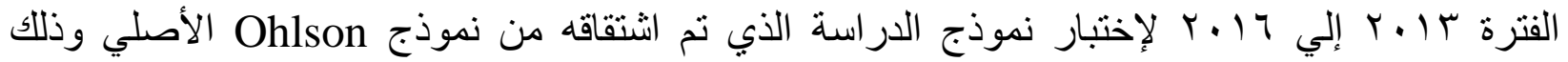

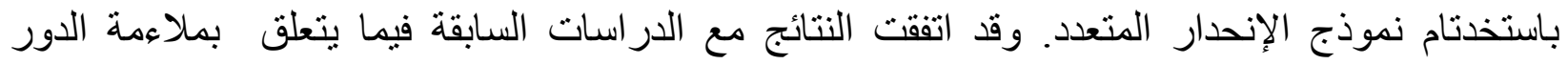

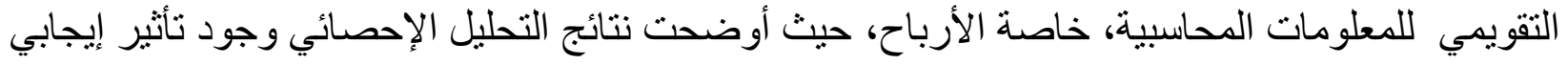

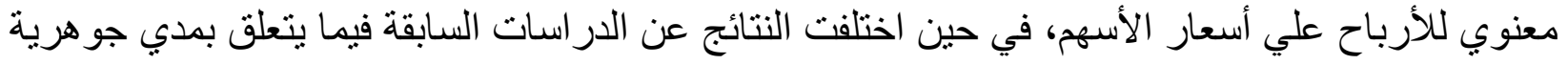

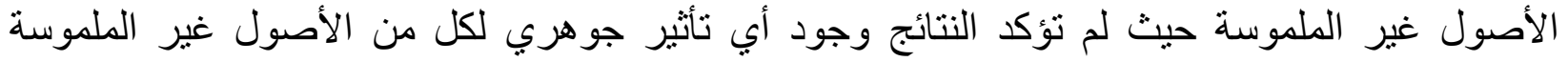

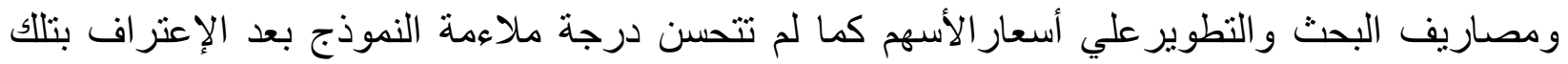

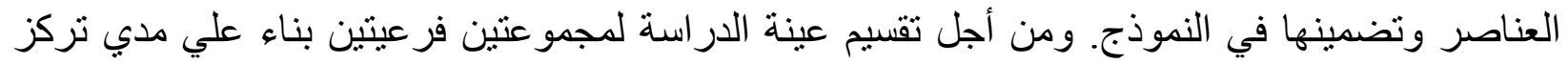

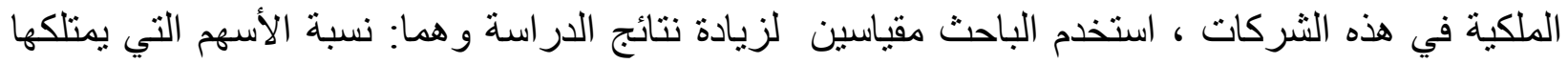

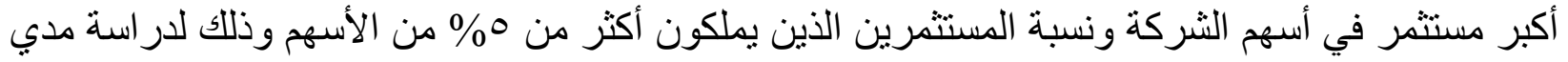

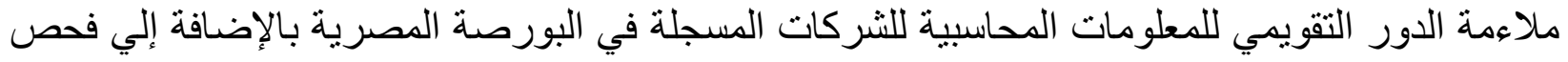

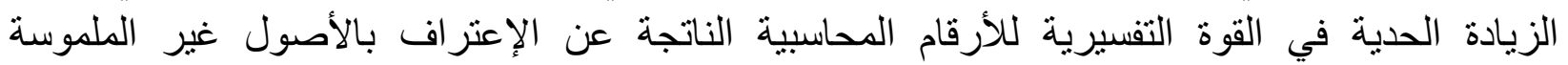

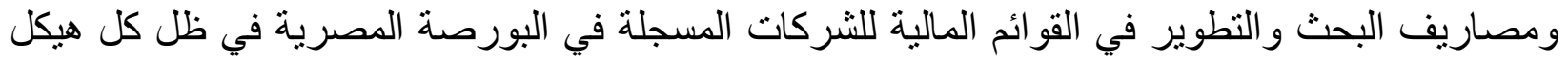

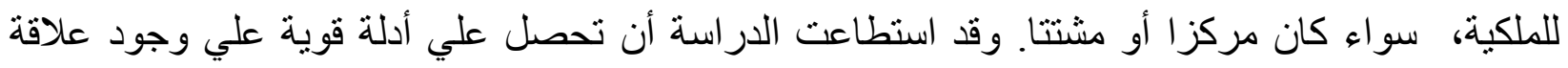

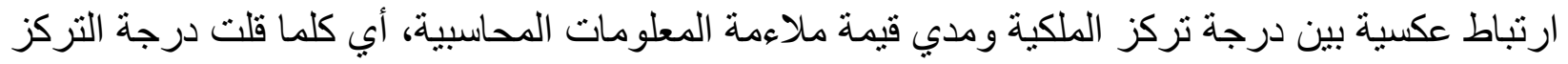

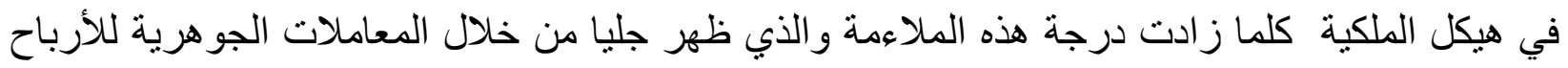

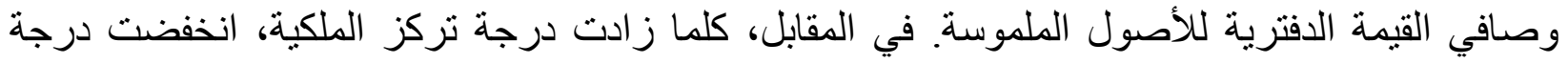

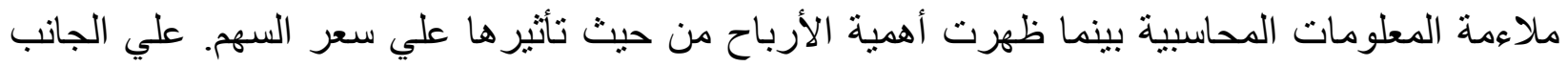

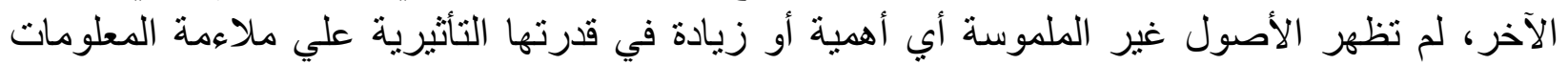
المحاسبيةلأغر اض فيلس القيمةفي ظل كل هيكل للملكية سو اء كان مركز أو أو مشتئا.

الكلمات المفتاحية:ملاعمة المعلومات المحاسبية لأغراض قيلس القيمة ، الأصول غير الملموسة، نفقات

البحث و التطوير، تركز الملكية. 


\section{Introduction}

Financial accounting aims to satisfy users' needs with financial information that is helpful in decision making (Kimounche and Rouabhi 2016). According to the IASB(1989), financial statements aim to provide users with financial information about the firm's financial position, results of operations and its cash flows. Accordingly, most investors make their decisions based on accounting numbers (ElShandidy 2014). Whether or not the accounting information is linked to investors' decisions becomes an issue that attracted researchers' attention (E1Shandidy 2014).

The usefulness of accounting information had always been referred to in the accounting literature by the term "value relevance" (Kimounche and Rouabhi 2016)which aims to measure the usefulness of accounting information to stock investors(Beisland 2009). According to the academic literature, value relevance analysis focus on the relation between accounting numbers and stock market prices as proxies of firm value (Giosi et al 2013).Accounting numbers are considered to be value relevant if there is a statistically significant effect of these numbers on the market value of the firm and in contrast, accounting numbers are not value relevant if those numbers do not have a significant positive effect on market prices of the firm (Pervan and Batulovic 2013). However, Collins et al (1997) noticed that the movement from industrialized economies to high technology oriented economies had caused a loss in the value relevance of financial statements data. This by turn resulted in widening the gap between the firm's book value and market value (Beattie 2005). (Ghaharmanizady and Behname 2013) explained such a problem by referring to the conservative nature of the asset recognition criteria imposed by accounting standards that restricted the ability of the firm to recognize some of the intangible assets and in turn adversely affects the relevance of financial information provided by these firms to their investors. The severe competition and the advancement of new information technologies had shed light on the importance of intangibles as vital source of corporate value (Lev 2001 cited in Ghaharmanizady and Behname 2013).

In this paper, the terms intangible assets and intellectual capital are used synonyms based on the definitions provided by the great majority of research in the area of intangibles (Cuozzo et al 2017). 


\section{Research Problem}

\section{Based on the above discussion, the study aims to answer the following questions}

Is accounting information value relevant for companies listed in the Egyptian stock market and is this level of value relevance of accounting information (if any) and the relative importance of accounting numbers affected by the level of ownership concentration?

Is the value relevance of the accounting informationfor companies listed in the Egyptian stock market (if any)improvedby the inclusion of intangibles and is such level of value relevance affected by the level of ownership concentration?

\section{Research Importance and Motivation}

Reporting intangible assets has become one of the most issues that had received lots of debate at the levels of the academic literature and business practice due, in part to the growing gap between the book value and market value of companies and the difficulties related to recognizing intangible assets in financial statements (Kang and Gray 2011). Disclosing information about intangibles is important for two reasons, the first of which is the movement towards globalization resulted in the capital markets of developing countries are becoming more exposed to investors in any part all over the globe. Those investors require higher levels of relevance and reliability of information on company's financial performance and look for increasing levels of transparency about the firm's corporate value including disclosures about intangible assets. The second reason is the growing demand for harmonization in developed markets and in new emerging economiesrequires an analysis of the current reporting practices of emerging market companies, and determining the reasons beyond the differences in business reporting practices for recognition and disclosure of intangible assets such as accounting regulations and type of industry.

Chen et (2001) pointed that the strength of value relevance of accounting information in developing economies is declining compared to developed markets due to several reasons, the first of which is the transitory nature of the stock markets in developing economies resulting in

different issues kept unresolved which may motivate firms in the market to manipulate accounting numbers in their financial statements and also due to the lack of laws that protect investors' rights. In addition, Chen et al (2001) also referred to theweak accounting and auditing practices in specific and the lack of sufficient corporate governance practices could adversely 
affect investors' confidence in financial statements' information which in turn might reduce the value relevance of accounting information in developing countries.

This study is one of few studies that aim to explore the value relevance of accounting information for companies listed in the stock market in Egypt as no other studies according to the owner's best interest had tried to explore this topic in the Egyptian stock market except Ragab and Omran's (2006) study which was conducted in the period of 1998-2002 before adoption of IFRS by Egyptian companies and prior to the changing conditions of the Egyptian economy. This paper aims to extend the previous work by investigating the incremental value relevant effect ofdisclosing information about intangibles whether in the balance sheet as intangible assets or in the income statement as R\&D expenses by companies listed in the Egyptian stock market using different ownership concentration structures. In other wards, the researcher aims to explore whether information about intangibles complement the primary information provided by the firm to investors through the book value of equity and earnings. In addition, the study aims to examine the relative explanatory power of accounting numbers in affecting the firm market value of equity and examining the effect of different ownership structures on improving the value relevance of accounting information and the significance of accounting numbers. This is done by regressing the market value of firm's stock prices on the different accounting variables introduced in the study (Lev and Zarowin 1999 and Barth et al 2008). The paper is organized as follows; section (2) presents the literature review, section (3) discusses the hypotheses development and formulation of research hypotheses, section (4) includes the research design and results of the empirical study.

\section{Literature review}

The issue of value relevance had attracted the attention of researchers in accounting over several decades resulting in a stream of empirical studies analyzing the relevance of traditional accounting numbers to investors in order to examine the ability of financial statements to provide useful information to those investors (Ghaharmanizady and Behname 2013). According to (Francis \& Schipper, 1999), the value relevance measures the ability of financial statements to capture and summarize information that can be reflected in firm's value. So in order for accounting information to be value relevant, numbers in the financial statements must be associated with the current market value(Kimounche and Rouabhi 
2016).Value relevance research is the empirical assessment of the usefulness of financial information in decision making and is a joint test for the two fundamental qualitative characteristics of accounting information according to the IFRS conceptual framework which are faithful representation (known previously as reliability) and relevance (Barth et al 2001).

The origin of value relevant research can be traced back to the Ball and Brown study (1968) who found a strong association between earnings announcements and abnormal returns in the months surrounding the announcements. Their results were extended by Beaver (1968) who examined the effect of earnings announcements on the trading volume of stocks and provided evidence that the volume of traded stocks significantly increased in the week where an announcement of earnings is made. In addition, Beaver (1986) also found that the magnitude of change in stock prices in the week where an earnings announcement is made is higher in comparison to other weeks where no trading announcements were made.

However, several research studies asserted that the value relevance of accounting information is steadily decreasing for both earnings and book value (Lev and Zarowin 1999); they indicated a gap between the market value of the firm and book values of equity resulting from the reduction in the value relevance of accounting information. Francis and Schipper (1999) explained the reason to the static accounting practices applied in a dynamic business environment or due to the changes in these practices in a way that did not help in increasing the value relevance of accounting information. Lev and Zarowin (1999) added in this context that the declining value relevance of accounting information can be explained by the increasing pace of changes in the business environment and the shortcomings of the accounting standards to reveal those changes.

Lev (1989)also noticed such a decline in the value relevance of accounting numbers as he found a low statistical association between earnings and stock returns indicated by the coefficient of determination $\left(\mathrm{R}^{2}\right)$ that reached below $10 \%$ in some cases or even zero in others. Lev (2001) attributed such a reduction to the existence of a gap due to the inability of accounting standards to account for intangible assets that increased in their importance to be a vital source of value to the firm representing the transition from a tradition physical asset oriented economy to a technology based one (Lev 2001). Goldfinger (1997) had also provided the same explanation as he argues that the transition to a knowledge based economy 
where tangible assets are becoming less important and that the main source of value comes from the intangible assets. Such inability to accurately recognize intangible assets impacts the value relevance of each of equity and earnings (Goldfinger, 1997). Hasso (2013) added in this respect that such a failure on the part of accounting standardshas made financial information less accurate in portraying the value of the firm, thus becoming of less value relevance for the users of these statements.

The International Accounting Standard Board exerted lots of efforts to improve the standards related to the identification, recognition, measurement and disclosures for intangible assets and to improve the usefulness of accounting numbers in the financial statements. Current reporting requirements for intangibles have been included in AASB (IFRS 3 Business Combinations) (IAS 38) Intangible Assets. According to AASB 138 "Intangible Assets"; only externally purchased good will and other identifiable intangibles as patents and licenses are to be capitalized and recorded as intangible assets and accordingly are subjected to an impairment test. With respect to Research and Development costs, research costs should be expensed immediately while development costs can be capitalized. For good will with infinite life, the standard was less conservative in this context, as this type of intangibles needn't be amortized over twenty years instead they are subjected to regular impairment test which permits managers to apply some of their discretion. From a signaling theory perspective, such a discretion left to managers when applying the impairment test, can cause them to use the goodwill in providing a better value for the firm. On the other hand, from an agency theory perspective, managers may abuse this discretionary power to realize their own goals at the expense of shareholders ( $\mathrm{Ji}$ and Lu 2014).

According to agency theory, managers are not always taking decisions to maximize the value of the firm for the sake of shareholders (Thomson and Pederson 2000). Owners aim to maximize their wealth and profits while managers look for maximizing their compen sation, reducing the efforts they exert in doing their work in addition to their preference of some expenses over others and their aims for empire buildings (Chandrapala 2013). Shareholders are not directly involved in the management process and the presence of information asymmetry between the principal and agent helps in intensifying the moral hazard problem which could be abused by managers taking advantage of the information gap and behave in an opportunistic manner to realize their own goals at the expense of the owners (Zhang 2012). When intangible assets especially those intangible assets related to intellectual 
capital is intensively involved in the business process, the intensity of the agency costs and the information asymmetry are expected to be more apparent (Alves and Martins 2010) which requires much more monitoring by owners and greater disclosure of management activities (Jensen and Meckling 1976) This requires a stronger corporate governance mechanism to protect minority shareholders and ensure their receipt of better information so that they won't be expropriated by majority shareholders (Bushman and Smith 2003).That's why the association between ownership concentration as a monitoring mechanism on the value relevance of accounting numbers in the financial statements is worth studying (Chandrapala 2013).

A dispersed (non concentrated) ownership structure means that the fraction of shares of each shareholder is less than $5 \%$ of all ownership shares there are no one shareholder or group of shareholders in the firms who neither have voting power or an incentive to exercise control or maximize the firm's profits (Strick 2011). This in turn implies the distribution of risk among a large number of shareholders which gives room for higher management specialization (Thomson and Pederson 1999). From an agency theory perspective, these small shareholders miss the contractual mechanisms that allow them to link managers' interests with their interests. This gives management a space to control the company's resources and act according to their own interests (Leaven and Levine 2008), which could result in a vertical agency problem between small investors and firm's management (Strick 2011). In contrast, in a concentrated ownership, one large shareholder owns an apparent fraction of all shares implying a significant power and control over company managementto narrow the previously mentioned gap between shareholders and managers. However, another gap is widened between those controlling shareholders and other minority shareholders who aim to expropriate the firm's resources at the expense of other non controlling shareholders with minority interests (Pederson and Thomsen 2000) resulting in a horizontal gap between those two types of shareholders (Strick 2011)

\section{Hypotheses development}

The Ohlson model (1995) led to a wide stream of research in the area of value relevance. Collins et al (1997) studied the value relevance of accounting numbers on a sample of 119,389 firm year observations of American firms over a period of forty years from 1953 to 1993 using earnings and book value of equity individually and jointly. They found that each 
of the two variables is value relevant and that both of them jointly explain more than $50 \%$ of changes in the firm's stock prices and that such percentage did not decrease over the sample period but had shown slight increase. Chen et al (1999) conducted an empirical study on the value relevance of accounting information in the Chinese market. They provided evidence on the value relevance of accounting information to investors regardless of the fact that the Chinese market is an emerging market and despite investors' perceptions of inadequate financial reporting practices in the Chinese market. Ragab and Omran (2006) performed an empirical analysis to examine the value relevance of earnings and book value of equity in the Egyptian stock market in the period starting from 1998 to 2002 using Ohlson's 1995 price model. They proved the existence of a strong value relevant relationship for both earnings and book value of equity and they justified their findings due to the less prevalent nature of other sources of financial information to investors in the Egyptian market compared to their counterparts in more mature economies such as earnings forecasts reports published by financial analysts. They also examined the value relevance of earnings using Ohlson's return model but they detected an insignificant relationship between earnings and the changes in returns on stocks. They attributed such finding to the myopic nature of investors in the Egyptian stock market and their emphasis on earnings values rather than the rate of changes in these earnings.Accordingly, the first hypothesis could be stated as follows:

\section{$H_{1}:$ A positive relationship exists between the market value of the firm's equity and accounting information for companies listed in the Egyptian stock market.}

With respect to the relation between ownership concentration and the value relevance of accounting information, studies provided mixed evidence. For example, using a sample of U.S. companies, Wang (2006) found that higher ownership concentration was reflected in improving the quality of earnings. Based on a sample of 435 European companies, Thomson and Pederson (2000) was able to provide evidence of a positive association between ownership concentration on one hand and each of market to book value of equity and the firm's return on assets (ROA) on the other hand.

In contrast, Fan and Wong (2002) argued that concentrated ownership reduces the informativeness of earnings figures in East Asian countries, they explained that as the concentration of ownership is increased, the shareholder owning a controlling number of 
shares tries to obtain full control of the firm to realize private interests at the expense of minority shareholders such as maintain cash inside the company to work on building their empire, the problem becomes worse when such controlling shareholders control the recruitment of top management in the company. Such an agency conflict between controlling shareholders and minority shareholders inversely affects the earnings-return relation.

Bae and Jeong (2007) studied a sample of Korean firms and provided evidence that the value relevance of earnings and book value is significantly lower for firms where ownership is concentrated in an individual or a single family due to his increased control rights which is used by this owner to maximize his own wealth at the expense of the value of the firm. These actions taken by the owner would then be reflected in the firm's earnings and book value which could stimulate regulatory bodies and other small investors to take some disciplinary actions against the firm. This in turn could motivate the owner to hide the firm's real performance to reduce outsiders interference in the firm's own affairs or could stimulate owners to reduce their dependence on financial statement numbers disclosed by these types of firms as they will be expecting that those numbers included in the financial statements reflects owner's interest rather than the true economic value of the firm (Bae and Jeong 2007). Lim (2012) added in this respect that those controlling shareholders and managers would prefer an opaque information environment that could enable them to abuse remaining shareholders and hide the consequences of their manipulative behavior for the sake of their private interests at the expense of other non-controlling shareholders which can be adversely reflected in the value relevance of accounting information.

Accordingly, the first hypothesescould be formulated as follows:

\section{$H_{1 a}$ : The level of value relevance of accounting information for companies listed in the} Egyptian stock market is affected by the level of ownership concentration

Recent research had also been extended to the relative ability of accounting numbers to affect the market value of firm's equity. For example, Barth et al (1998) noticed that the relevance of the firm's book value of equity is inversely related to the financial health of the company; that is as the financial health of the company deteriorates, the relevance of the book value of equity for explaining changes in firm's market value is reduced. In contrast, 
Barth et al (1998) found a significant positive association between the value relevance of earnings figures and the market value of its equity. Several papers had studied the effect of ownership concentration on firm performance and financial health. For example, Thomsen and Pedersen (2006) studied a sample of 276 firms from the European Union and found that block ownership had a significant negative impact on firm's performance. Accordingly, the financial health of firms where ownership is highly concentrated is expected to be deteriorating due to poor corporate governance mechanisms, it is expected that the value relevance of book value would be higher in firms where the ownership is concentrated compared to firms where ownership is dispersed. Accordingly, the third hypothesis could be stated as follows:

H1 $1_{b}$ The relative value relevance of accounting numbers for companies listed in the Egyptian stock market varies in concentrated ownership structures than non concentrated ownership structures

The growing gap between the market value and the book value of firm's equity had catalyzed a stream of research on the importance of reporting intangibles and their value relevance to market participants (Morricone et al2009). Voluntary disclosure practices of intangibles can provide great assistance to companies working in emerging economies as compared to companies working in mature markets as the first lack enforceable high quality accounting standards compared to the latter given the case that those companies in emerging economies need to disclose more information to attract more foreign investors to their countries(Kang and Gray2011). Studies were also concerned with the value relevance of different types of intangibles as capitalized software costs, goodwill, patents, capitalized R\&D expenses to investors and their explanatory power of changes in firm's stock prices. Most of these studies found a positive significant effect of these items on the value relevance of accounting information. Several authors had examined the value relevance of including R\&D expenses on the market value of the firm, for example, Green et al (1996) conducted a regression analysis to study the effect of the book value of the firm's equity, research and development expenses and income before $R \& D$ on market value of those firm's equity. They found that R\&D expenses had a positive significant effect on market value of the firm's equity and they attributed these results to perceptions of market perceptions who viewed $\mathrm{R} \& \mathrm{D}$ expenses as capitalized expenditures. Tsoligkas and 
Tsalavoutas(2011) distinguished between the capitalized and expensed portion of R\&D and he was able to provide evidence that the part of $R \& D$ being capitalized is positively perceived by market participants viewing these types of expenditures as a starting point for promising projects for the firm in the future. However, the market negatively viewed any expensed R\&D expenses as they viewed this part as encompassing no benefits in the future. On the other hand, Stark and Thomas (1998) replicated the previous study but using income before extraordinary items not final earnings numbers reached the same conclusions by Green et al (1996). Akbar and Stark (2003) also were able to reach the same results as previous studies.

Accordingly, the second hypotheses could be formulated as follows

\section{$\mathrm{H}_{2}$ : The incremental value relevance of accounting information for companies listed in the Egyptian stock market is increased by the disclosure of intangibles information}

Hasso (2013) noticed that the value relevance of intangible assets differs in family owned firms where ownership is concentrated within the same investor than non-family owned firms where the ownership is dispersed among different investors due to the nature of family firms that result in the accumulation of intangible assets. Hasso (2013) attributed these differences to two reasons, the first is social capital that according to his point of view is inherent to the presence of the owner to the extent that the presence of the firm is related to the name of the owner, therefore, firms where ownership is concentrated with a single owner, place greater emphasis on social capital generating activities when compared to their counterparts whose ownership is dispersed among many owners as developing firms' reputation which is linked to the owner's reputation, strengthening the relationship with value chain partners, developing new markets aiming to improve the financial performance of the firm over the long run. The second reason for these differences according to Hasso (2013) is related to human capital.

Miller et al (2008) showed that in firms when ownership is concentrated, more investment is devoted to human capital related activities such as investment in training and flexible work arrangements which positively impacts firm performance and productivity to the extent that human capital in these firms is identified as the most important intangible asset.Accordingly, the second hypothesis could be formulated as follows 
$H_{2 a}:$ The incremental value relevance of intangibles for companies listed in the Egyptian stock market varies in concentrated ownership structures than in non concentrated ownership structures

\section{Research Methodology}

\subsection{Study population and sampled data}

The study is examines public non-financial Companies listed in the Egyptian stock Market Authority during the period from 2013 to 2016 from all economic sectors of the economy according to the capital Market Authority Classification which reached a total of 141 firms resulting in 374 year observations after excluding any missing data for any specific year was excluded from the sample. Banks and other financial institutions were not included in the sample due to comparability issues because of differences in asset and capital structure; variables included in the models are not appropriate for banks, finance companies and other similar companies (Gunathilaka 2014). Corporate annual reports are used as the main source of data to obtain relevant information needed for the study. Market prices are obtained from website of http://www.mubasher.info/countries/eg/stockprices. The study period was selected so that all reports released by firms during this period were adopting the same accounting framework which is the IFRS. Checks were made that any intangible asset data disclosed by sampled firm for the year 2016 were not affected by the Egyptian Accounting standards issued in 2015 and applied on firms starting from 2016. This provides assurance that all tested data are prepared under the same accounting framework.

\subsection{Measurement of the variables Used in the study}

This section is concerned with describing the variables used in the study

\section{a. Dependent Variable}

Market Value of Equity $\left(\mathbf{M V}_{i t}\right)$ calculated by multiplying the market price of the firm's common stock $i$ three months after the end of its fiscal year by the number of common shares outstanding on that date (Chebaane and Othman 2014 and Salehi (2013)so that the market reaction to earnings' announcement is incorporated in the stock price (Ghaharmanizady and Behname 2013). 


\section{Independent variables}

Earnings before Interest and Taxes $\left(\right.$ EBIT $\left._{i t}\right)$ : This variable is used as an indicator for company's earnings according to Ohlson (1995) valuation model. According to Strik (2011) it is considered a better measure of earnings as it includes operating elements and it exclude non recurring items (Che 2007 and $\mathrm{Xu}$ and $\mathrm{Lu}$ 2014). A positive significant effect is expected to be realized between this variable and the market value of firm's equity

Net Total Tangible Assets (NTTA $\mathbf{A}_{i t}$ ): This is book value of common equity for firm $i$ after deducting intangible assets capitalized in year $t$ (Ghaharmanizady and Behname 2013). This variable is measured by the difference between total tangible assets (current assets plus fixed assets) minus total liabilities ( $\mathrm{Xu}$ and $\mathrm{Lu}$ 2014). This measurement can be used as an indicator of the reliability of information about intangibles as it is expected that market participants would provide more value for firms with positive tangibility (high solidity) [NTTA>0] levels compared to other firms with negative tangibility (low solidity) $[$ NTTA $<0]$ on the basis that those firms with positive tangibility can cover all their liabilities and have no incentive to capitalize intangibles to overstate their total assets and better reflect their financial position ( $\mathrm{Xu}$ and $\mathrm{Lu}$ 2016). Accordingly a positive association is expected to exist between this variable and the market value of firm equity.

Total Intangible Assets (TIA ${ }_{i t}$ ): This variable refers to the capitalized total intangible assets reported by the company iin its balance sheet in the period t including goodwill and other intangible assets (Morricone et al 2009, Salehi et al 2013, Xu and Lu 2014, Kimouche and Rouabhi 2016). Intangible assets mostly recognized by companies included in the study are goodwill, computer software programs, production rights, trademarks, capitalized R\&D costs and franchises). Accordingly, the provision of information about intangibles in the balance sheet is expected to complement book value and earnings numbers and increase the value relevance of accounting information (Morricone et al 2009)

Research and Development Expenses (R\&D $i t)$ :Studies have used R\&D expenditures as an indicator for internally generated assets which could not be capitalized by the firms due to the failure of these internally generated assets to satisfy the asset recognition requirement in compliance with IAS 38 and examined how the inclusion of these items could increase the value relevance of accounting information (Lev and Zarowin (1999). Accordingly, the inclusion of $R \& D$ expenses in the income statement is expected to 
complement book value and earnings numbers and increase the value relevance of accounting information (Morricone et al 2009)

\section{b. Control variables:}

Firm size (FS): Is considered an essential variable that could affect the level of disclosureby the firm as it is suggested that as that large companies are expected to increase their disclosure levels (Kang and Gray 2011) and is widely used as a control variable in the disclosure literature where a positive association is expected between the firm size and the value relevance of accounting informationincluding intangibles (Zhang 2012). According to many studies, it is measured by the natural log of total assets (Gong and Wang 2016). Alali and Foote (2012) used the median of the natural log of total assets as a discriminating point to distinguish between firms of large sample size and small sample size. Accordingly, a firm is considered large in size if the natural $\log$ of its total assets is greater than the sample's median and in contrast, the firm is considered small in size if the natural log of its total assets is less than or equal the sample median. This variable will be denoted by $\left(\mathrm{FS}_{\mathrm{it}}\right)$ and is included in the analysis as a dummy variable taking the value of (1) if the firm is large in size and a value of (0) if the firm is small in size

Leverage (Levit): It measures the degree to which the firm depends on others in financing its operations. According to the agency theory, companies with leverage ratios have more incentives to provide better information as creditors exert a monitoring power over the firm's management to protect their debt covenants and managers attempt to increase disclosure to reduce costs associated with this agency relationship. In addition, management of highly leveraged firms may be much more motivated to recognize intangibles, to satisfy restrictions imposed by debt covenants or to improve the firm's borrowing capacity. Accordingly, a positive association is expected between the firm's leverage ratio and the relevance of accounting information including intangibles. It is measured by the ratio of total liabilities to total assets at the end of the year (Anadarjan and Hasan 2010). The study will follow (Martinez et al 2014) in measuring leverage, where the median of the leverage values for the whole sample is considered a discriminating point to distinguish between high leveraged and small leveraged firms. This means that the firm will be considered as a highly leveraged firm if its leverage ratio is greater than the median of the whole sample leverage and vice versa, the firm is classified as a low leverage firm if its leverage percentage is lower than or equal the leverage median for the whole sample.Accordingly, this variable will also be included in the study as a dummy variable 
taking a value of (1) if the firm is classified as a highly leveraged firm and a value of (0) if the firm is classified as a low leverage firm

Direction of firm's operation $\left(\mathbf{L O S S}_{\mathbf{i t}}\right)$ : It refers to the direction of operations as being profits or losses. This variable will be used in the study as a dummy variable taking a value of (1) in case of losses and (0) in case of profits. This is based on Okafar et al (2016) that the goodness of fit of value relevance decreases in the case of losses in regression, even without the reduction in the informativeness of accounting variables taking into consideration that losses are less informative than profits. Accordingly a negative relationship is expected between this variable and the market value of firm's equity

Type of Audit Firm (AUDit): This variable refers to the type of the audit firm as being a big four or non big four. Firms audited by a big audit firm are expected to disclose more information and to be better valued by investors compared to other firms audited by a nonbig four audit firm. Accordingly, a positive relationship is expected between the type of the audit firm and the market value of its equity in addition to the value relevance of accounting information including intangibles(Omoye 2013)

\section{c. Ownership concentration}

Studies performed on the concentration of ownership had used different measures the most important of which is percentage of ownership shares by the largest investor as a proxy to differentiate between ownership concentrated firms and non concentrated. If one of the firm's shareholder owns more than $50 \%$ of ownership shares, the firm is classified as a concentrated ownership firm and the opposite is true (Thomsen and Pedersen (2000 and Chandrapala 2013). Based on this proxy, sampled data are classified into two groups, the first includes 218 firms where the largest shareholder owns less than 50\% of all ownership shares and is therefore classified as firms with dispersed or non concentrated ownership firms and the other 157 firms are classified as concentrated where the largest shareholder owns more than $50 \%$ of ownership shares.

Another proxy for ownership concentration is block holders ownership percentage, this refers to the total percentage of shareholders who own shares of 5\% of the company common stocks (Holderness 2010 and Thomsen and Pedersen 2006). If the total ownership percentage of block holders more than $50 \%$, then the firm is classified as having a concentrated ownership structure and the opposite is true. Based on this criteria, sampled data are classified into two groups, the first includes 95 firms where block holders owns less than 
$50 \%$ of all ownership shares and is therefore classified as firms with dispersed or non concentrated ownership firms and the other 280 firms are classified as having a concentrated ownership structure where the total block holders ownership percentage is more than 50\%.

The following table provides a summarized description of study variables

\begin{tabular}{|c|c|c|c|}
\hline Study Variables & Measurement & Notation & $\begin{array}{l}\text { Expected } \\
\text { Direction }\end{array}$ \\
\hline \multicolumn{4}{|c|}{ Dependent Variable } \\
\hline $\begin{array}{l}\text { Market value of } \\
\text { equity }\end{array}$ & $\begin{array}{l}\text { Market price of the firm's common stock } 3 \\
\text { months after the end of its fiscal year } \\
\text { multiplied by the number of shares } \\
\text { outstanding on that date ((Salehi et al 2013) }\end{array}$ & $M V$ & \\
\hline \multicolumn{4}{|c|}{ Independent Variables: } \\
\hline $\begin{array}{l}\text { Adjusted Book } \\
\text { value of Equity }\end{array}$ & $\begin{array}{l}\text { Total current Assets + Total Fixed assets } \\
\text { except intangibles }- \text { Total Liabilities }\end{array}$ & NTTA & $\beta_{l}$ Positive \\
\hline & $\begin{array}{l}\text { (Ghaharmanizady and Behname } 2013 \text { and Xu } \\
\text { and Lu 2014); }\end{array}$ & & \\
\hline $\begin{array}{l}\text { Earnings before } \\
\text { Interest and Taxes }\end{array}$ & $\begin{array}{l}\text { Net Operating Income (exclude non } \\
\text { recurring items) (Xu and Lu 2014) }\end{array}$ & $E B I T$ & $\beta_{2}$ Positive \\
\hline $\begin{array}{l}\text { Total intangible } \\
\text { Assets }\end{array}$ & $\begin{array}{l}\text { All intangible assets reported by firms in } \\
\text { the Balance Sheet (Morricone et al 2009) }\end{array}$ & TIA & $\beta_{7}$ Positive \\
\hline $\begin{array}{l}\text { Research and } \\
\text { Development } \\
\text { expenses }\end{array}$ & $\begin{array}{l}\text { All research and Development costs } \\
\text { reported by firms in the income statement } \\
\text { (Morricone et al 2009) }\end{array}$ & $R \& D$ & $\beta_{8}$ Positive \\
\hline \multicolumn{4}{|l|}{ Control Variables } \\
\hline Firm Size & $\begin{array}{l}\text { a dummy variable taking a value of (1) if } \\
\text { the firm is classified as a highly leveraged } \\
\text { firm and a value of (0) if the firm is } \\
\text { classified as a low leverage firm (Gong and } \\
\text { Wang 2016) }\end{array}$ & $F S$ & $\beta_{3}$ Positive \\
\hline Leverage ratio & $\begin{array}{l}\text { a dummy variable taking a value of (1) if } \\
\text { the firm is classified as a highly leveraged } \\
\text { firm and a value of }(0) \text { if the firm is } \\
\text { classified as a low leverage firm (Martinez } \\
\text { et al 2014) }\end{array}$ & $L E V$ & $\beta_{4}$ Positive \\
\hline $\begin{array}{l}\text { Direction of } \\
\text { operations }\end{array}$ & $\begin{array}{l}\text { A dummy variable taking a value of (1) in } \\
\text { case of losses and (0) in case of profits. } \\
\text { (Okafar et al 2016) }\end{array}$ & LOSS & $\beta_{5}$ Negative \\
\hline
\end{tabular}


Audit firm size A dummy variable taking the value of (1) in case the firm is audited by a big four audit

firm and (0) otherwise(Omoye 2013)

Table (1) Measurement of study variables

\subsection{Research Model :}

\section{The value relevance model of accounting information}

To test research hypotheses, the researcher had used two main models; the first is theoriginal Ohlson-model (Ohlson 1991) and (Feltham and Ohlson 1995); included the two main essential accounting measurements which are book value of equity and earnings.It is based on the idea that the book value of equity and earnings are expected to be unbiased estimators of market value of stock prices in assuming no other factors will change the relation between book value and market value relation(Feltham and Ohlson 1995); Accordingly, the first price model can be formulated as follows ( $\mathrm{Xu}$ and $\mathrm{Lu} 2014$ ).

$M V_{i t}=\alpha_{i, t}+\beta_{1} N T T A_{i t}+\beta_{2} E B I T_{i t}+\beta_{3} F S_{i t}+\beta_{4} L e v_{i t}+\beta_{5} L O S S_{i t}+\beta_{6} A U D_{i t}+e_{i t}$

$\mathrm{MV}$ is the total market value of equity of the firm at the end of three months after financial year

NTTA $_{i t}$ : is Net Total Tangible Assets of firm $\mathrm{i}$ at year $\mathrm{t}$

EBIT $_{i t}$ : Is the earnings before interest and tax of firm $i$ at year $t$.

$\mathrm{FS}_{\mathrm{it}}$ Isthe size of firm $i$ at year $t$ :

Levit:Is theleverage of firm $i$ at year $t$ :

LOSS $_{\mathrm{it}: I s}$ an indicator for firm's $i$ direction of operations in year $t$,

$\mathrm{AUD}_{\mathrm{it}} \mathrm{Is}$ the size of audit firm $i$ at year $t$

$e_{i t}:$ Is the error term

The second two modelsare based on Collins et al.'s (1997) modified version of the Ohlson's (1995) model. It is one of the most widely used models to test the ability of accounting information to inform capital market participants through explaining the reasons beyond the differences between the firm's book value and market value. Several studies are conducted by adding more accounting numbers to the modified Ohlson valuation model (Che 2007) and since studies of the value relevance of intangibles focused on testing the ability of intangible 
information disclosed in the firm's annual reports to explain firm's market value (Zhang 2012), the researcher will examine the incremental power of intangibles whether intangible assets (Morricone et al 2009 and $\mathrm{Xu}$ and $\mathrm{Lu}$ 2014) or R\&D expenses ( Morricone et al 2009 and Tsoligkas and Tsalavoutas 2011) to improve the explanatory power of the modified Ohlson model depending on the rationale that the growing gap between the market value of the firm and its book value reduced the value relevance of accounting information due to the inability of quantitative data to predict the changes in the market value of equity implying a need for non quantitative data such as intangibles (Abhayawansa and Guthrie, 2010).

Accordingly, the following two price models will be used which are derived from Ohlson-

Collins model originally derived from Ohlson theory and (Feltham and Ohlson 1995)

Model 2:(Xu and Lu2014).

$M V_{i t}=\alpha_{i, t}+\beta_{1} N T T A_{i t}+\beta_{2} E B I T_{i t}+\beta_{3} F S_{i t}+\beta_{4} L E V_{i t}+\beta_{5} L O S S_{i t}+\beta_{6} A U D_{i t}+\beta_{7} T I A_{i t}+e_{i t}$

Model 3 (Tsoligkas and Tsalavoutas 2011)

$M V_{i t}=\alpha_{i, t}+\beta_{1} N T T A_{i t}+\beta_{2} E B I T_{i t}+\beta_{3} F S_{i t}+\beta_{4} L E V_{i t}+\beta_{5} L O S S_{i t}+\beta_{6} A U D_{i t}+\beta_{7} T I A_{i t}+\beta_{8} R \& D_{i t}+e_{i t}$

TIA $_{i t}$ :Intangible assets for firm $i$ at year $t$

$\mathrm{R} \& \mathrm{D}_{\mathrm{it}}$ : Is the Research and Development Expensesreported in the income statement by firm $i$ in year $t$

\subsection{Descriptive Statistics:}

The following table (2) provides a descriptive statistics of study variables

\begin{tabular}{lrrrrrr} 
& \multicolumn{1}{c}{ Mean } & \multicolumn{1}{c}{ Median } & \multicolumn{1}{c}{ Std. Deviation } & Minimum & Maximum & Obs \\
\hline MP & $5.8155 \mathrm{E} 9$ & $2.2103 \mathrm{E} 8$ & $5.22967 \mathrm{E} 10$ & 4025000.00 & $6.68 \mathrm{E} 11$ & 375 \\
NTTA & $1.0159 \mathrm{E} 9$ & $2.3211 \mathrm{E} 8$ & $4.26677 \mathrm{E} 9$ & $-2.69 \mathrm{E} 10$ & $4.99 \mathrm{E} 10$ & 375 \\
EBIT & $2.4546 \mathrm{E} 8$ & 32423158.0000 & $1.05837 \mathrm{E} 9$ & $-5.46 \mathrm{E} 8$ & $1.16 \mathrm{E} 10$ & 375 \\
TIA & 28163903.7520 & .0000 & $2.01911 \mathrm{E} 8$ & .00 & $2.17 \mathrm{E} 9$ & 375 \\
R\&D & 407765.3787 & .0000 & 2687102.97622 & .00 & 31205987.00 & 375 \\
log assets & 20.0212 & 19.9668 & 1.61755 & 15.32 & 24.88 & 375 \\
Leverage & .4066 & .4076 & 5.04291 & $-46.50-$ & 75.14 & 375 \\
LOSS & $3.0534 \mathrm{E} 8$ & 27789834.0000 & $1.60899 \mathrm{E} 9$ & $-5.60 \mathrm{E} 8$ & $2.91 \mathrm{E} 10$ & 375 \\
audit firm type & .4053 & .0000 & .49161 & .00 & 1.00 & 375 \\
largest investor & 42.8092 & 42.1479 & 24.27204 & .00 & 99.99 & 375 \\
block holders \% & 63.5345 & 66.8000 & 22.20539 & .00 & 100.00 & 375
\end{tabular}

Table (2) Descriptive statistics for all variables in the model 


\subsection{Testing multicollinearity}

\section{Univariate analysis (correlation matrix) to test the association between variables}

The following table provides a correlation matrix between study variables

\begin{tabular}{|c|c|c|c|c|c|c|c|c|c|}
\hline & TMP & NTTA & EBIT & Size & LEV & DOP & AUD & TIA & $R \& D$ \\
\hline TMP & 1.000 & & & & & & & & \\
\hline NTTA & $\begin{array}{c}0.067 \\
(0.096)\end{array}$ & 1.000 & & & & & & & \\
\hline EBIT & $\begin{array}{l}0.315^{*} \\
(0.000)\end{array}$ & $\begin{array}{c}0.056 \\
(0.141)\end{array}$ & 1.000 & & & & & & \\
\hline Size & $\begin{array}{l}0.102^{*} \\
(0.024)\end{array}$ & $\begin{array}{l}0.240^{*} \\
(0.000)\end{array}$ & $\begin{array}{l}0.120^{*} \\
(0.010)\end{array}$ & 1.000 & & & & & \\
\hline LEV & $\begin{array}{c}0.083 \\
(0.053)\end{array}$ & $\begin{array}{c}0.017 \\
(0.374)\end{array}$ & $\begin{array}{c}0.036 \\
(0.243)\end{array}$ & $\begin{array}{l}0.211^{*} \\
(0.000)\end{array}$ & 1.000 & & & & \\
\hline LOSS & $\begin{array}{l}-0.023 \\
(0.328)\end{array}$ & $\begin{array}{l}0.389^{*} \\
(0.000)\end{array}$ & $\begin{array}{c}0.080 \\
(0.061)\end{array}$ & $\begin{array}{c}0.166 \\
(0.001)\end{array}$ & $\begin{array}{c}0.003 \\
(0.478)\end{array}$ & 1.000 & & & \\
\hline AUD & $\begin{array}{l}0.118^{*} \\
(0.011)\end{array}$ & $\begin{array}{l}0.171^{*} \\
(0.000)\end{array}$ & $\begin{array}{l}-0.018 \\
(0.364)\end{array}$ & $\begin{array}{l}0.241 * \\
(0.000)\end{array}$ & $\begin{array}{l}0.263^{*} \\
(0.000)\end{array}$ & $\begin{array}{l}-0.021 \\
(0.340)\end{array}$ & 1.000 & & \\
\hline TIA & $\begin{array}{l}-0.011 \\
(0.413)\end{array}$ & $\begin{array}{c}0.073 \\
(0.079)\end{array}$ & $\begin{array}{l}-0.006 \\
(0.451)\end{array}$ & $\begin{array}{c}0.113 \\
(0.014)\end{array}$ & $\begin{array}{l}-0.044 \\
(0.200)\end{array}$ & $\begin{array}{l}-0.003 \\
(0.479)\end{array}$ & $\begin{array}{c}-0.051 \\
(0.162)\end{array}$ & 1.000 & \\
\hline R\&D & $\begin{array}{l}-0.013 \\
(0.398)\end{array}$ & $\begin{array}{c}0.064 \\
(0.109)\end{array}$ & $\begin{array}{l}-0.018 \\
(0.362)\end{array}$ & $\begin{array}{c}0.044 \\
(0.199)\end{array}$ & $\begin{array}{l}-0.005 \\
(0.465)\end{array}$ & $\begin{array}{l}-0.001 \\
(0.495)\end{array}$ & $\begin{array}{c}0.070 \\
(0.087)\end{array}$ & $\begin{array}{l}-0.020 \\
(0.351)\end{array}$ & 1.000 \\
\hline
\end{tabular}

Table (3) Correlation Matrix of study variables

Results revealed the absence of multicollinearity between the variables being studied as correlation was less than $65 \%$ for the main study variables and VIF was less than 10 for all the variables included in the study.

\section{Statistical Analysis and results of testing research hypotheses}

This section presents the results of examining the study hypotheses

\subsection{Results of Testing Research Hypothesis $H_{1}$ :}

To test the first hypothesis $\left(\mathrm{H}_{1}\right)$ concerned with the relationship between accounting numbers and firm market value of the firm's stock prices, a multivariate linear regression analysis of model (1) was conducted on poled sample data as shown by table (4). Analysis of the significance of the coefficients of the study variables provided information about their relevance (Dahmash et al 2009 and Kallapur and Kwan 2004).Results showed a significant positive effect of earnings before interest and taxes (EBIT) on the market value of firm's equity (positive coefficient of $0.314, \mathrm{t}-$ stat $=6.359, \mathrm{p}$-value $=0.000<0.05$ ). The book value of firms' equity represented by the net value of total tangible assets after excluding liabilities did not show a significant positive effect on the firm's market value of equity as evidenced by the variable's coefficient $(0.053, \mathrm{t}-\mathrm{stat}=0.975, \mathrm{p}$-value $=0.330>0.05)$. The 
control variables encompassing firm size, leverage, net income direction and type of audit firm did not show any significant positive effect on the firm's market value of equity. This results in partially accepting hypothesis H1confirming the significant positive effect of accounting numbers represented byEBIT on market value of equity for firms listed in the Egyptian stock market.This also partially agrees with Ohlson (1995), Chen et al (2006) Ragab and Omran (2006) concerning the existence of the significant positive effect of accounting numbers namely earnings on stock prices but the study was not able to support those previous studies in finding a significant effect of net book value of the firm on stock market prices.

\begin{tabular}{|c|c|c|c|c|c|c|c|c|c|}
\hline & \multicolumn{3}{|c|}{$\begin{array}{c}\text { Model 1 } \\
\mathbf{N}=375\end{array}$} & \multicolumn{3}{|c|}{$\begin{array}{c}\text { Model } 2 \\
\text { N-375 }\end{array}$} & \multicolumn{3}{|c|}{$\begin{array}{c}\text { Model } 3 \\
\mathrm{~N}=375\end{array}$} \\
\hline & Coeff. & t-stat. & Sig & coeff & t-stat & sig & coeff & t-stat & Sig \\
\hline Constant & & -1.343 & .180 & & -1.322 & .187 & & -1.294 & .196 \\
\hline NTTA & .053 & .975 & .330 & .054 & .987 & .324 & .055 & 1.005 & .315 \\
\hline EBIT & .314 & 6.359 & .000 & .314 & 6.344 & .000 & .313 & 6.327 & .000 \\
\hline FS & .032 & .614 & .540 & .034 & .636 & .525 & .034 & .646 & .519 \\
\hline LEV & .040 & .772 & .441 & .039 & .759 & .448 & .039 & .748 & .455 \\
\hline LOSS & -.072 & -1.351 & .177 & -.073 & -1.359 & .175 & -.074 & -1.367 & .173 \\
\hline AUD & .095 & 1.811 & .071 & .094 & 1.785 & .075 & .095 & 1.802 & .072 \\
\hline TIA & & & & -.011 & -.219 & .827 & -.011 & -.229 & .819 \\
\hline$R \& D$ & & & & & & & -.020 & -.398 & .691 \\
\hline $\begin{array}{l}\mathrm{R}^{2} \text { (sig of } \\
\text { previous } \mathrm{r}\end{array}$ & $\begin{array}{l}\text { hange co } \\
\text { el) }\end{array}$ & ared to & & & 0.34 & $0.827)$ & & 0.35 & $0.691)$ \\
\hline F-statistic & ob) & & $(0.000)$ & & 7.28 & $0.000)$ & & 6.38 & $0.000)$ \\
\hline Predictors & NTTA, E & $\Gamma, \mathrm{FS}, \mathrm{LE}$ & SS, AUD & NTTA, I & $\begin{array}{l}\text { IT, TIA, F } \\
\text { SS, AUD }\end{array}$ & $\mathrm{EV}$ & $\begin{array}{r}\text { NTTA, } \mathrm{I} \\
\text { LE }\end{array}$ & $\begin{array}{l}\text { IT, TIA, } \\
\text { LOSS, A }\end{array}$ & $\mathrm{D}, \mathrm{FS}$ \\
\hline
\end{tabular}

\subsection{Results of Testing Research Hypothesis $H_{1 a}$ :}

To test hypothesis $\mathrm{H}_{1}$ a, sampled data were classified into two parts based on the degree of ownership concentration Two proxies were used by the researcher to measure the concentration of ownership; the first was the percentage of shares owned by the largest shareholder of the firm and the second was the percentage of shares owned by shareholders in blocks of $5 \%$ (block holders)

Table (5) and (6) presents a descriptive statistics of study variables based on the percentage of ownership concentration 


\begin{tabular}{lrrrrrr}
\hline & \multicolumn{1}{l}{ Mean } & \multicolumn{1}{l}{ Median } & St. Dev & Mean & Median & Std. Dev \\
\hline MP & $1.2279 \mathrm{E} 9$ & $2.1889 \mathrm{E} 8$ & $3.24419 \mathrm{E} 9$ & $1.2186 \mathrm{E} 10$ & $2.2103 \mathrm{E} 8$ & $8.04486 \mathrm{E} 10$ \\
NTTA & $9.4726 \mathrm{E} 8$ & $2.0110 \mathrm{E} 8$ & $4.87942 \mathrm{E} 9$ & $1.1111 \mathrm{E} 9$ & $2.8842 \mathrm{E} 8$ & $3.24220 \mathrm{E} 9$ \\
EBIT & $2.4792 \mathrm{E} 8$ & 37278777.5000 & $9.14787 \mathrm{E} 8$ & $2.4203 \mathrm{E} 8$ & 29939204.0000 & $1.23344 \mathrm{E} 9$ \\
TIA & 40080257.1514 & .0000 & $2.59791 \mathrm{E} 8$ & 11617629.6051 & .0000 & 58158635.96942 \\
R\&D & 353637.5872 & .0000 & 2993413.25298 & 482923.7134 & .0000 & 2199236.97638 \\
log assets & 20.0001 & 20.0390 & 1.66957 & 20.0505 & 19.9131 & 1.54721 \\
Leverage & .7081 & .3617 & 5.06880 & $-.0122-$ & .5026 & 4.99261 \\
LOSS & $2.0546 \mathrm{E} 8$ & 34778159.5000 & $4.34344 \mathrm{E} 8$ & $4.4402 \mathrm{E} 8$ & 18544290.0000 & $2.43123 \mathrm{E} 9$ \\
$\begin{array}{l}\text { AUD } \\
\text { largest }\end{array}$ & .3991 & .0000 & .49084 & .4140 & .0000 & .49413 \\
investor & 25.7872 & 25.3955 & 12.20972 & 66.4448 & 60.0000 & 15.42427
\end{tabular}

Table (5) descriptive statistics of firms based on the \% of shares owned by the largest shareholder

As shown in table (5) where data is classified based on the first proxy (percentage of shares owned by the largest shareholder), 218 firms (58.1\% of the whole sample) are classified as having non-concentrated ownership (dispersed) as the mean percentage of ownership shares owned by the largest shareholder is $25.7872 \%$ with standard deviation of 12.20972 and 157 firms (representing $41.9 \%$ of the sample) are classified as concentrated ownership as the mean percentage of ownership shares owned by the largest shareholder is $66.4448 \%$ with standard deviation of $15.4274 \%$

\begin{tabular}{|c|c|c|c|c|c|c|}
\hline & \multicolumn{3}{|c|}{$\begin{array}{c}\text { Dispersed ownership } \\
\text { \% of block holders }<50 \% \\
\mathrm{~N}=95 \\
\end{array}$} & \multicolumn{3}{|c|}{$\begin{array}{c}\text { Concentrated ownership } \\
\% \text { of block holders }>\mathbf{5 0 \%} \\
\mathrm{N}=\mathbf{2 8 0} \\
\end{array}$} \\
\hline & Mean & Median & Std. Dev & Mean & Median & Std. Dev \\
\hline MP & $6.7809 \mathrm{E} 8$ & 78193236.2400 & 1.70493E9 & $7.5585 \mathrm{E} 9$ & 2.7922E8 & $6.04416 \mathrm{E} 10$ \\
\hline NTTA & $9.5425 \mathrm{E} 8$ & 97707682.0000 & $2.94988 \mathrm{E} 9$ & $1.0368 \mathrm{E} 9$ & 3.0179E8 & 4.63366E9 \\
\hline EBIT & 68194784.1684 & 11843107.0000 & $1.54090 \mathrm{E} 8$ & 3.0560E8 & 38678187.5000 & 1.21623E9 \\
\hline $\mathrm{IA}$ & 17085278.5789 & .0000 & 89534330.00144 & 31922723.0071 & .0000 & 2.27800E8 \\
\hline$R \& D$ & 2226.8105 & .0000 & 10036.54696 & 545358.8214 & .0000 & 3099046.63201 \\
\hline $\log$ ass & 19.3463 & 19.0155 & 1.61578 & 20.2502 & 20.2319 & 1.55564 \\
\hline Leverage & .3118 & .2717 & .21294 & .4387 & .4473 & 5.83702 \\
\hline LOSS & 75129655.1895 & 13948603.0000 & $1.35922 \mathrm{E} 8$ & $3.8344 \mathrm{E} 8$ & 31399260.5000 & $1.85471 \mathrm{E} 9$ \\
\hline AUD & .4316 & .0000 & .49792 & .3964 & .0000 & .49003 \\
\hline block & 33.2844 & 38.2806 & 14.05191 & 73.7979 & 72.7640 & 13.30978 \\
\hline holders & & & & & & \\
\hline
\end{tabular}

Table (6) descriptive statistics of firms based on bock holders' concentration percentage 
On the other hand, table (6) presents the whole sample data classified according to the percentage of block holders' ownership, it can be shown that 95 firms $(25.3 \%$ of sampled data) are classified as having non-concentrated ownership (dispersed) with a mean percentage of ownership shares owned by block holders is $33.284 \%$ with standard deviation of 14.050191 and 280 firms (74.7\% of sampled data) are classified as concentrated ownership as the mean percentage of ownership shares owned by block holders is 73.7979 $\%$ with standard deviation of $13.0978 \%$

To test hypothesis H1a, a multivariate linear regression analysis was performed for each of the subsamples using each ownership proxy. The level of value relevance for each of the two subsamples classified under each ownership proxy were compared based on the value of $\mathrm{r}^{2}$; this is the coefficient of determination (explanatory power) which measures the proportion of variance in the dependent variable explained by the independent variable(s) (Beisland 2009). In other wards, $r^{2}$ is a measure of how much variation in stock prices can be explained by the accounting measure being studied. By comparing such explanatory power from one sample to the other, the extent to which value relevance differs between samples (Beisland 2009)can be determined. The following table shows the results of multivariate regression for model (1) after classifying the sample into parts first using the percentage of shares owned by the largest shareholder as proxy for ownership concentration structure (panel A) and percentage of block holder ownership (panel B) as the second proxy

\begin{tabular}{|c|c|c|c|c|c|c|c|c|}
\hline & \multicolumn{4}{|c|}{ Panel A } & \multicolumn{4}{|c|}{ Panel B } \\
\hline & \multicolumn{4}{|c|}{ Largest shareholder Ownership } & \multicolumn{4}{|c|}{ Block holder \% ownership } \\
\hline & \multirow{2}{*}{\multicolumn{2}{|c|}{$\begin{array}{l}\text { Dispersed ownership } \\
\text { No. of obs. }=218\end{array}$}} & \multirow{2}{*}{\multicolumn{2}{|c|}{$\begin{array}{l}\text { Con. Ownership } \\
\text { No. of obs. }=157\end{array}$}} & \multirow{2}{*}{\multicolumn{2}{|c|}{$\begin{array}{l}\text { Dispersed ownership } \\
\text { No. of obs. }=95\end{array}$}} & \multirow{2}{*}{\multicolumn{2}{|c|}{$\begin{array}{l}\text { Con. Ownership } \\
\text { No. of obs. }=280\end{array}$}} \\
\hline & & & & & & & & \\
\hline & Coeff. & Sig. & Coeff & Sig & Coeff. & Sig. & Coeff & Sig \\
\hline Constant & & .505 & & .309 & & .278 & & .208 \\
\hline N TTA & .500 & .000 & .121 & .258 & .446 & .000 & .058 & .363 \\
\hline EBIT & .112 & .050 & .405 & .000 & .198 & .001 & .311 & .000 \\
\hline Size & .231 & .000 & .021 & .793 & .138 & .044 & .042 & .483 \\
\hline LEV & -.098 & .085 & .049 & .542 & -.059 & .285 & .038 & .521 \\
\hline LOSS & -.017 & .782 & -.138 & .187 & -.401 & .000 & -.078 & .214 \\
\hline AUD & .052 & .363 & .125 & .123 & -.034 & .537 & .113 & .065 \\
\hline $\mathrm{R}^{2}$ & 0.6 & & 0.46 & & 0.894 & & 0.35 & \\
\hline Adjusted $\mathrm{R}^{2}$ & 0.3 & & 0.18 & & 0.786 & & $0.10^{7}$ & \\
\hline F-statistic (prob) & 21.520 & 00) & 6.774 & 00) & $58.478(0.0$ & & $6.551(0$. & \\
\hline
\end{tabular}

Predictors Model (1) NTTA, EBIT, FS, LEV, LOSS, and AUD

Estimator : Total market value of firm's equity three months after financial statements date Table (7) Multivariate regression for concentrated and non concentrated firms

As shown in the above 6 [panel A], regression analysis using the first proxy (percentage of shares owned by the largest shareholder) shows that the coefficient of determination $r^{2}$ for the ownership dispersed firms is $61.6 \%(\mathrm{~F}$ - statistic $=21.520$, p-value $=0.000<0.05)$ while the corresponding value for the ownership concentrated firms is $46.2 \%$ (F- statistic $=6.774$, 
p-value $=0.000<0.05)$. The difference in $r^{2}$ is $15.4 \%$ in favor of firms with dispersed ownership concentration. Regression results using the second proxy (block holders' ownership percentage) [table 7, panel B] showed that the $\mathrm{r}^{2}$ for firms dispersed in their ownership structure is $89.4 \%($ F-statistic $=58.478$, p-value $=0.000<0.005)$ while the corresponding number for the ownership concentrated firms is $35.5 \%$ (F-statistic $=6.551$, p-value $=0.000<0.05)$. The difference in $r^{2}$ is $53.9 \%$ in favor of firms with dispersed ownership structure showing that the value relevance of accounting information is significantly higher for dispersed ownership firms compared to firms with concentrated ownership which agree with providing evidence to strongly accept hypothesis $\mathbf{H}_{1 a}$ which supports the stakeholder theory asserting that low concentrated ownership structures means the existence of a large number of dispersed and diversified stakeholders which enforces the company to disclose more information to satisfy those different stakeholder groups (Coremier et al 2005). These results contradicts results provided by Chandrapala (2013), Wang 2006, and Thomas and Pederson 2000 but it confirms Fan and Wong (2002), Bae and Jeong (2007) and Lim (2012) where the latter group believed that the low value relevance of accounting numbers in highly concentrated structures due to owners' abuse of their control rights at the expense of non-controlling shareholders. The contradiction in the results obtained by these two groups can be attributed to the nature of markets where the studied had been conducted;as it can be noticed that studies conducted on firms working in mature stock markets enjoy strong monitoring mechanisms that could limit any manipulative behavior on the part of controlling shareholders that could threaten the interests of non controlling shareholders. In contrast, studies performed on firms operating in emerging less mature markets including Egypt, a significant reduction in the value relevance of accounting information in the concentrated group compared to the non concentrated group which could be explained by the absence of laws and monitoring mechanisms that could limit owners' intervention which causes other non controlling owners to loose faith in the firm's accounting numbers reflected in the significant deterioration of accounting information in these concentrated structures as compared to non concentrated structures

\subsection{Results of Testing Research Hypothesis $H_{1 b}$ :}

Hypothesis $\mathrm{H}_{1 b}$ is concerned with examining the relative significance of accounting numbers in changing the market value of firm's equity under each ownership structure. Results from table 7 [panel A] shows that in case of first proxy (\% of shares owned by the 
largest shareholder), book value of equity measured by the net book value of total tangible assets after deducting liabilities (NTTA) had a significant positive effect on changes in market prices as made obvious by the positive coefficient of the this variable (coefficient $=$ $0.500, \mathrm{p}$-value $=0.000<0.05)$ in the dispersed ownership structure compared to the concentrated group where the $\mathrm{p}$-value of this coefficient was insignificant ( $\mathrm{p}$-value $=0.258$ > 0.05). However, earnings figures as measured by the EBIT showed a significant positive effect on market prices in the concentrated owner ship structure ( $\mathrm{p}$-value $=0.000<0.005$ ) compared to the other subsample where ownership structure is dispersed. It can also be noted that the size of the firm had a significant positive effect on market value in dispersed ownership structures (coefficient $=0.231$, p-value $0.000<0.05$ ) as compared to the corresponding concentrated structures which revealed no evidence for the effect of firm size or any other control variable on changes in the market value of firm' equity.

Using the other proxy for ownership concentration (\% of block holder ownership) [Table 7, panel B] shows that for dispersed ownership structures, net total tangible assets, earnings before interest and taxes, and firm size showed a significant positive effect on the market value of equity as depicted by their positive significant coefficients ( $\mathrm{p}$ - values $=0.000$, 0.001 and $0.044<0.05$ respectively where direction of operations showed an inverse significant effect on value relevance of accounting information. On the other hand, analysis of the concentrated ownership structure revealed that EBIT was the only significant variable in the model as shown by its positive coefficient ( $p$ - value $=0.000<0.05$ ). This provides a strong support for accepting hypothesis $\mathbf{H}_{1 b}$ showing that the value relevance of accounting numbers differs significantly with changes in the firm's ownership structure and that the more dispersed the ownership structure of the firm, the higher the value relevance of accounting numbers. These results confirms Barth et al (1998) who advocated that the value relevance of accounting information is inversely related to the financial health of the firm and if we assumed based on the previous discussion that investors doubt the financial health of firms with concentrated ownership structures, this could interpret the increased significant effect of EBIT in firms with concentrated structures compared to their counterparts with non concentrated structures.

\section{4. $\quad$ Results of Testing Research Hypothesis $\mathrm{H}_{2}$ :}

Hypothesis $\mathrm{H}_{2}$ is concerned by the incremental change in the value relevance of accounting information resulting from the disclosure of intangibles information whether in the balance sheet (Model 2) or in the income statement (model 3). Model 2 is examined using a 
multivariate linear regression analysis to measure the ability of intangible assets reported by firms in their balance sheets in addition to firm's income numbers and book value of equity to affect the market value of firm's equity. Statistical analysis of model (2) as shown in table (4) revealed that the only accounting number still having a significant effect in the model was EBIT $(\mathrm{t}-$ stat 6.344 , $\mathrm{p}$-value $=0.00<0.05)$ and that intangible assets did not have a significant positive effect on market prices of equity ( $\mathrm{t}$-stat $=-0.219, \mathrm{p}$-value 0.827 ). That's why the level of the value relevance of accounting information remained the same compared to model 1 which did not include any intangibles; the coefficient of determination $\mathrm{r}^{2}=0.349$ in both models (1) and (2) resulting in an insignificant change in adjusted $r^{2}$ between models (2) and (1) 0.827>0.05) (Che 2007).

With respect to model (3), that is concerned with testing the ability of accounting numbers including intangibles and R\&D expenses to affect the changes in the market value of firm's equity. Statistical analysis of model (3) as represented in table (3) also showed that the only accounting number having a significant effect on market value of equity was EBIT ( $t$-stat 6.327 , $p$-value $=0.00<0.05$ ) that $R \& D$ expenses did not have a significant positive effect on market prices of equity ( $\mathrm{t}-\mathrm{stat}=-0.398$, p-value $0.691>0.05$ ). Accordingly, the level of the value relevance of accounting information showed an insignificant increase of $0.01 \%$ compared to the basic model $1\left(r^{2}=0.350\right.$ in model 3 , significance of $r^{2}$ change compared to model 1 is $0.158>0.05$ ).thus, resulting in rejecting hypothesis $\mathbf{H}_{2}$ providing evidence that intangible assets did not have a significant effect on changes in market prices and neither on improving the value relevance of accounting information. This result could be justified by users' doubt of the reliability of the accounting methods used to measure intangibles as the relevance of intangibles depend on the reliability of measuring them causing the signals sent by the firms to the users of its financial reports through intangibles incompletely understood by them (Xu and Lu 2014)

\subsection{Results of Testing Research Hypothesis $\mathrm{H}_{2 a}$ :}

To test hypothesis $\mathrm{H}_{2 a}$ that is concerned with whether the incremental change in the value relevance of accounting information resulting from the disclosure of intangibles information whether in the balance sheet (Model 2 as intangible assets) or in the income statement (model 3 as R \& D expenses) is affected by the firm's ownership structures as being concentrated or non-concentrated. Statistical analysis of model (2) as shown in table (8) revealed that with the inclusion on intangible assets in the modelusing the first proxy for ownership concentration [panel A], intangible assets did not show any significant effect (pvalue $>5 \%$ for each of the two subsamples) and the value relevance for the model did not 
show any significant changes compared to model (1) as the coefficient of determination remained 0.622 with significance of change for $r^{2}=2.585>5 \%$ for the dispersed ownership structure and the same applies to the concentrated ownership structure with a very slight and insignificant improvement in $r^{2}=0.465$ compared to 0.462 in model (1) resulting in an insignificant change in adjusted $\mathrm{r}^{2}$ of $0.567>0.05$. Analysis of the second proxy revealed the same results as the first one where intangible assets did not show any significant effect on market prices and the value relevance of $r^{2}$ remained the same when compared to their corresponding values in the first model.

\begin{tabular}{|c|c|c|c|c|c|c|c|}
\hline & \multicolumn{3}{|c|}{ Panel A } & \multicolumn{4}{|c|}{ Panel B } \\
\hline & \multicolumn{3}{|c|}{ Largest shareholder Ownership } & \multicolumn{4}{|c|}{ Block holder \% ownership } \\
\hline & $\begin{array}{l}\text { Dispersed ownership } \\
\text { No. of obs. }=218\end{array}$ & \multicolumn{2}{|c|}{$\begin{array}{l}\text { Con. Ownership } \\
\text { No. of obs. }=157\end{array}$} & \multicolumn{2}{|c|}{$\begin{array}{l}\text { Dispersed ownership } \\
\text { No. of obs. }=95\end{array}$} & \multicolumn{2}{|c|}{$\begin{array}{l}\text { Con. Ownership } \\
\text { No. of obs. }=237\end{array}$} \\
\hline & Coeff. $\quad$ Sig. & Coeff & Sig & Coeff. & Sig. & Coeff & Sig \\
\hline Constant & .433 & & .358 & & 0.250 & & .215 \\
\hline NTTA & .508 & .133 & .219 & 0.445 & 0.000 & .059 & .356 \\
\hline EBIT & .112 & .405 & .000 & 0.195 & 0.002 & .311 & .000 \\
\hline FS & .249 & .017 & .832 & 0.126 & .084 & .043 & .473 \\
\hline LEV & -.100 & .039 & .627 & -0.054 & .335 & .038 & .527 \\
\hline LOSS & -.027 & -.143 & .172 & 0.407 & .000 & -.079 & .211 \\
\hline AUD & .039 & .140 & .095 & -0.028 & .628 & .112 & .068 \\
\hline TIA & -.089 & -.057 & 0.453 & 0.025 & 0.640 & -.012 & .835 \\
\hline $\mathrm{R}^{2}$ & $0.622(2.585)$ & \multicolumn{2}{|c|}{$0.465(0.567)$} & \multicolumn{2}{|c|}{$0.894(0.220)$} & \multicolumn{2}{|c|}{$0.355(0.044)$} \\
\hline Adjusted $\mathrm{R}^{2}$ & 0.367 & \multicolumn{2}{|c|}{0.179} & \multicolumn{2}{|c|}{0.784} & \multicolumn{2}{|c|}{0.104} \\
\hline F-statistic (prob) & $18.953(0.000)$ & \multicolumn{2}{|c|}{$5.871(0.000)$} & \multicolumn{2}{|c|}{$49.711(000)$} & \multicolumn{2}{|c|}{$5.602(0.000)$} \\
\hline
\end{tabular}

Predictors Model (2) NTTA, EBIT, TIA, FS, LEV, LOSS, AUD

Estimator : Total market value of firm's equity three months after financial statements date

Table (8) Multivariate regression for concentrated and non concentrated firms using model 2

With respect to model 3, table (9)presents results of multivariate regression for each of the two subsamples based on the level of ownership concentration using the two ownership proxies used in the study. As shown in table (9) inclusion of R\&D expenses in the model using the first proxy for ownership concentration [panel A] shows that R\&D expenses did not show any significant effect on market prices ( $\mathrm{p}$-value $>5 \%$ for each of the two subsamples) and the value relevance for the model did not show any significant changes compared to the previous model as the coefficient of determination is 0.624 compared to an $r^{2}$ of 0.616 resulting in an insignificant change for adjusted $r^{2}$ of $0.706>5 \%$ for the dispersed ownership structure and the same applies to the concentrated ownership structure with a very slight and insignificant improvement in $r^{2}=0.468$ compared to 0.462 which is considered an insignificant change in adjusted $r^{2}$ of $0.480>0.05$. Analysis of the second proxy revealed the same results as the first one where R \&D did not show any significant effect on market prices and the value relevance of $r^{2}$ sowed slight insignificant improvements in the two sub samples when compared to their corresponding values in the previous models resulting in an insignificant change for adjusted $r^{2}$, resulting in rejecting 
hypothesis $\mathbf{H}_{2 a}$ implyingthat intangible assets and R\&D expenses did not have a significant effect on changes in the firm's market value of equity or in improving the value relevance of accounting information for firms listed in the Egyptian stock market regardless of changes in the level of ownership concentration. This could be also justified in the same way as hypothesis $\mathrm{H}_{2}$ where the investors' doubts concerning the reliability of measuring intangibles had adversely affected the relevance of accounting information resulting from the disclosure of these data in the firms' financial statements (Xu and $\mathrm{Lu} 2014$ )

\begin{tabular}{|c|c|c|c|c|c|c|c|c|}
\hline & \multicolumn{4}{|c|}{ Panel A } & \multicolumn{4}{|c|}{ Panel B } \\
\hline & \multicolumn{4}{|c|}{ Largest shareholder Ownership } & \multicolumn{4}{|c|}{ Block holder \% ownership } \\
\hline & \multicolumn{2}{|c|}{$\begin{array}{l}\text { Dispersed ownership } \\
\text { No. of obs. }=218\end{array}$} & \multicolumn{2}{|c|}{$\begin{array}{l}\text { Con. Ownership } \\
\text { No. of obs. }=157\end{array}$} & \multicolumn{2}{|c|}{$\begin{array}{l}\text { Dispersed ownership } \\
\text { No. of obs. }=95\end{array}$} & \multicolumn{2}{|c|}{$\begin{array}{l}\text { Con. Ownership } \\
\text { No. of obs. }=237\end{array}$} \\
\hline & Coeff. & Sig. & Coeff & Sig & Coeff. & Sig. & Coeff & Sig \\
\hline Constant & & .456 & & .468 & & .230 & & 0.232 \\
\hline NTTA & .505 & .000 & .170 & .160 & 0.444 & .000 & .061 & .344 \\
\hline FS & .254 & .000 & .009 & .130 & .127 & .083 & 0.044 & .470 \\
\hline LEV & -.100 & .078 & .035 & .102 & -.052 & .362 & 0.036 & .544 \\
\hline LOSS & -.029 & .648 & -.168 & .406 & .409 & .000 & -0.080 & .207 \\
\hline AUD & .045 & .444 & .137 & .490 & -.026 & .644 & 0.115 & .064 \\
\hline EBIT & .111 & .051 & .402 & .000 & 0.196 & .002 & .310 & 0.000 \\
\hline TIA & -.090 & .107 & -.064 & .913 & .026 & .632 & -0.13 & 0.825 \\
\hline $\mathbf{R} \& \mathbf{D}$ & -.046 & .402 & -.056 & .668 & .018 & .716 & -0.025 & 0.661 \\
\hline $\mathrm{R}^{2}$ & \multicolumn{2}{|c|}{$0.624(0.706)$} & \multicolumn{2}{|c|}{$0.468(0.480)$} & \multicolumn{2}{|c|}{$0.89590 .133)$} & \multicolumn{2}{|c|}{$0.356(0.193)$} \\
\hline Adjusted $\mathrm{R}^{2}$ & \multicolumn{2}{|c|}{0.366} & \multicolumn{2}{|c|}{0.176} & \multicolumn{2}{|c|}{0.782} & \multicolumn{2}{|c|}{0.101} \\
\hline F-statistic (prob) & \multicolumn{2}{|c|}{$16.649(0.000)$} & \multicolumn{2}{|c|}{$5.179(0.000)$} & \multicolumn{2}{|c|}{$43.081(0.000)$} & \multicolumn{2}{|c|}{$4.911(0.000)$} \\
\hline
\end{tabular}

Predictors Model (3) NTTA, EBIT, TIA, R\&D, FS, LEV, LOSS, and AUD

Estimator : Total market value of firm's equity three months after financial statements date

Table (9) Multivariate regression for concentrated and non concentrated firms using model 3

\section{Summary of hypotheses results}

The following table provides a summary of study hypotheses and their associated results based on the empirical analysis:

\begin{tabular}{|l|l|l|}
\hline $\begin{array}{l}\text { Hypothesis } \\
\text { No. }\end{array}$ & \multicolumn{1}{|c|}{ Statement of the hypothesis } & $\begin{array}{l}\text { Results } \\
\text { statistical } \\
\text { analysis }\end{array}$ \\
\hline $\mathrm{H} 1$ & $\begin{array}{l}\text { A positive relationship exists between the market value of } \\
\text { the firm's equity and accounting information for companies } \\
\text { listed in the Egyptian stock market. }\end{array}$ & $\begin{array}{l}\text { Partially } \\
\text { Accepted }\end{array}$ \\
\hline $\mathrm{H} 1 \mathrm{a}$ & $\begin{array}{l}\text { The level of value relevance of accounting information for } \\
\text { companies listed in the Egyptian stock market is affected by } \\
\text { the level of ownership concentration }\end{array}$ & Accepted \\
\hline $\mathrm{H} 1 \mathrm{~b}$ & $\begin{array}{l}\text { The relative value relevance of accounting numbers for } \\
\text { companies listed in the Egyptian stock market varies in } \\
\text { concentrated ownership structures than non concentrated }\end{array}$ & Accepted \\
\hline
\end{tabular}




\begin{tabular}{|l|l|l|}
\hline & ownership structures & \\
\hline $\mathrm{H} 2$ & $\begin{array}{l}\text { The incremental value relevance of accounting information } \\
\text { for companies listed in the Egyptian stock market is } \\
\text { increased by the disclosure of intangibles information }\end{array}$ & Rejed \\
\hline $\mathrm{H} 2 \mathrm{a}$ & $\begin{array}{l}\text { The incremental value relevance of intangibles for } \\
\text { companies listed in the Egyptian stock market varies in } \\
\text { concentrated ownership structures than in non concentrated } \\
\text { ownership structures }\end{array}$ & \\
\hline
\end{tabular}

\section{Additional Analysis}

An additional analysis was performed by the researcher to examine the combined effect of the two ownership proxies used in the study on the value relevance of accounting information.This will provide a better analysis of the relative effect of the different accounting numbers on the market value of the firm's equity under each ownership structure. This combination resulted in the following three subgroups as shown by the following table (10). The first is those firms with highest level of ownership dispersion (largest investor owns less than $50 \%$ of shares and the total block holder concentration percentage is less than $50 \%=95$ firms observations). The second group includes those firms where block holders \% of ownership exceeded $50 \%$ but the largest shareholder owns less than $50 \%$ of total shares $=123$ firms obs.). The last group is the one with the highest degree of concentrated ownership structure where the \% of block holders' ownership is more than $50 \%$ and can be concentrated in one shareholder =157). Analysis of those three groups using multivariate regression shows that the first group with the highest level of ownership dispersion structure showed a the greatest number of significant accounting variables as evident by the significant positive coefficient of those variables (book value of equity, earnings (EBIT), size and those firms direction of operations where their respective p-values $<5 \%)$ and the highest coefficient of determination $\left(\mathrm{r}^{2}=89.4 \%\right)$ compared to the other two subgroups. As the level of ownership concentration increases, the number of variables in the model showing a significant positive effect is reduced and the value relevance of the whole model is reduced; the second group of moderate ownership concentration shows a positive significant effect for book value of equity and firm size ( $\mathrm{p}$-value $<0$ ) where EBIT and firms' directions of operations became insignificant ( $p$-value $>0$ ) compared to the first group resulting in a reduction in the value relevance of the whole model $\left(\mathrm{r}^{2}=59.5 \%\right)$. Finally, the third subsample, with the highest level of ownership concentration, showed that 
only EBIT was the only significant variable in the model (p-value < 0) and all other variables are insignificant. In addition, the value relevance of the whole model is further reduced to reach $46.2 \%$ that is nearly half the value relevance percentage of the highest dispersed model showing that the concentration of ownership structure had a negative significant effect on the significance of accounting numbers in specific and the level of value relevance for accounting information in general.

\begin{tabular}{|c|c|c|c|c|c|c|}
\hline & \multicolumn{2}{|c|}{$\begin{array}{c}\text { High dispersion } \\
\text { Block holder }<50 \% \\
\text { largest } \mathrm{Sh}<50 \% \\
\mathrm{~N}=95\end{array}$} & \multicolumn{2}{|c|}{$\begin{array}{c}\text { Block holders }>50 \% \\
\text { Largest } \mathrm{Sh}<50 \% \mathrm{~N}=100 \\
\mathrm{~N}=123\end{array}$} & \multicolumn{2}{|c|}{$\begin{array}{l}\text { High concentration } \\
\text { Block holders }>50 \% \\
\text { Largest } \mathrm{Sh}>50 \% \\
\mathrm{~N}=157\end{array}$} \\
\hline & Coeff & Sig. & Coeff. & Sig. & Coeff & Sig \\
\hline Constant & & .278 & & .621 & & .309 \\
\hline NTTA & .446 & .000 & .489 & .000 & .121 & .258 \\
\hline EBIT & .198 & .001 & .115 & .143 & .405 & .000 \\
\hline FS & .138 & .044 & .174 & .038 & .021 & .793 \\
\hline LEV & -.059 & .285 & -.096 & .219 & .049 & .542 \\
\hline LOSS & .401 & .000 & -.072 & .406 & -.138 & .187 \\
\hline AUD & -.034 & .537 & .142 & .073 & .125 & .123 \\
\hline $\mathrm{R}^{2}$ & \multicolumn{2}{|c|}{0.894} & \multicolumn{2}{|c|}{0.595} & \multicolumn{2}{|c|}{0.462} \\
\hline Adjusted $\mathrm{R}^{2}$ & \multicolumn{2}{|c|}{0.786} & \multicolumn{2}{|c|}{0.320} & \multicolumn{2}{|c|}{0.325} \\
\hline F-statistic (stat) & \multicolumn{2}{|c|}{$58.478(0.000)$} & \multicolumn{2}{|c|}{$10.588(0.000)$} & \multicolumn{2}{|c|}{$6.774(0.000)$} \\
\hline
\end{tabular}

Model (1) NTTA, EBIT, FS, LEV, LOSS, AUD

Estimator : Total market value of firm's equity three months after financial statements date

Table (10): Multivariate analysis of the combined effect of the two ownership proxies

\section{Conclusions, Recommendations and Future Research Opportunities}

This paper is based on the value relevance analysis which aims to measure the usefulness of accounting information to stock investorsthrough testing the association between accounting numbers and stock market prices of the firm as a proxy for firm value. The growing gap between these accounting numbers and the market value of equity had stimulated a stream of research to investigate the reasons beyond this difference. Several studies had attributed such deterioration in the value relevance of accounting numbers to the severe competition and advancement of new information technologies that highlighted the importance of recognizing intangible assets as a vital source of value to the firm even though several studies criticized the conservative nature and asset recognition criteria imposed by accounting standards that restricted the firm's ability to recognize intangibles which could adversely affect the relevance of accounting information provided to investors.

The study builds on the original Ohlson model (Feltham and Ohlson 1995)that is based on the idea that earnings and book value of the firm's equity are the two unbiased estimators of the market value of stock prices and then studied the incremental effect of adding each of total 
intangible assets and $R \& D$ expenses on the value relevance of accounting information. Results agreed with previous studies concerning the value relevance of accounting information especially earnings and provided evidence for the presence of a positive significant effect between this accounting figure and the market value of firm's equity. However, results provided by the study contradicted those of previous studies with respect to the significance of intangibles as no evidence was found for the presence of any significant effect on the part of total intangible assets and $R \& D$ expenses on stock market prices and the value relevance of the whole model did not show any incremental development after the recognition of intangible assets or $R \& D$ expenses.

To further analyze the value relevance of accounting information and the associated incremental effect associated with the recognition of intangibles, two proxies were used to classify the sampled data into dispersed and concentrated structures which are the percentage of shares owned by the largest investor and the block holders' percentage of ownership. The study provided a strong evidence for the existence of an inverse association between the percentage of ownership concentration and value relevance of accounting information; i.e. the less concentrated the firm's ownership structure, the higher the value relevance of accounting information represented by the positive significance of earnings and book value of equity. In contrast, high concentrated ownership structures showed lower levels of value relevance with earnings numbers becoming more significant. Intangibles did not show any significance or value relevance in either of the two ownership structures.

Accordingly, the researcher recommend that accounting researches should devote more attention to the study at the academic and practical level due to the importance of the topic to investors and stock market participants in general, establishing a data base at the Egyptian stock market based on companies' ownership structures so that the data base could be classified to concentrated and non concentrated firms accompanied by the closing stock prices of listed companies. The researcher also recommends the inclusion of the research topic in $\mathrm{Ph}-\mathrm{D}$ courses taught in Egyptian Universities and finally calling for conferences by accounting departments to discuss topics related to the research study to raise awareness about the importance of intangibles to the value relevance of accounting information and as a vital source of data to market participants. 
Finally, future research studies are recommended to examine the value relevance of accounting information in banks, financial institutions and insurance companies based on their ownerships structures as being concentrated or non concentrated. The value relevance of intangibles could also be performed through a comparative analysis between the different industrial sectors with special emphasis on those sectors that depend on high technology. Research studies could examine the effect of audit quality and auditor industry specialization on the value relevance of accounting information including intangibles. Fruitful results could be obtained if the models included in the study are replicated using interim financial reports that could provide more detailed analysis of study results. Finally, more research studies should be devoted to examining the effect of IFRS adoption on the value relevance of accounting information including intangibles. 


\section{References}

- Abhayawansa, S. and Gutherie J. (2010) "Intellectual Capital and the market capital: A review and synthesis" Journal of Human Resource Costing and Accounting, 14(3):196226

- Akbar, S. and Stark, A.W. (2003) "Deflators, net shareholder cash flows, dividends, capital contribution and estimated models of corporate valuation" Journal of Business, Finance and Accounting. 30,1211-1233

- Alali, Fatima .A. and Paul.Sheldon. Foote, 2012, " The Value Relevance of International Financial Reporting Standards: Empirical Evidence in an Emerging Market".The International Journal of Accounting, Vol. 47. pp. 85-108.

- Alves, S. and Martins, J. (2010) "The impact of intangible assets on financial and governance policies: UK evidence" International Research Journal of Finance and Economics, 36: 147-169

- Anandarajan, A. I. Hasan, 2010, " Value Relevance of Earnings: Evidence from Middle Eastern and North African Countries", Advances in Accounting, incorporating Advances in International Accounting, Vol. 26, pp. 270-279.

- Bae, Kee-Hong and Seok Woo Jeong (2007) "The value relevance of earnings and book value, Ownership Structure and Business Group Affiliation: Evidence from Korean Business Groups" Journal of Business Finance and Accounting, 34 (5) \& (6), 740-766.

- Ball, R. and Brown, P. (1968) "An empirical evaluation of accounting income numbers" Journal of Accounting Research, 6(20), pp. 159-178

- Barth, M.E Beaver, W.H. and Landsman, W.R. (1998) "Relative valuation roles of equity book value and net income as a function of financial health" Journal of Accounting and Economics 25 (1), 1-34

- Barth, M.E., Beaver W.H. and Landsamn W.R. (2001) "The relevance of the value relevance literature for financial accounting standard setting: Another view" Journal of Accounting and Economics, 31 (1-3), 77-104.

- Barth, M. E., Landsman, W. R. and Lang, M. (2008) "International accounting standards andaccounting quality,"Journal of Accounting Research, 46(3), pp. 467-498. 
- Beisland, Leif Atle (2009) "A Review of the Value Relevant Literature" The Open Business Journal 2-27.

- Beaver, W. H. (1968) "The Information Content of Annual Earnings Announcements" Journal of Accounting Research, 6(3), 67-92.

- Bushman, R. M. and Smith, A. J. (2003) “ Transparency, financial accounting information and corporate governance" Economic Policy review, 9 (1); 65-87

- Chandrapala, Pathirawsam (2013) “The Value Relevance of Earnings and Book value: The Importance of Ownership Concentration and Firm Size" Journal of Competitiveness, Vol 5, Issue 2, pp. 98-107 (DOI):10.7441/joc.2013.02.07

- Che, Bo (2007) "Value - relevance of accounting information and shareholding structure in emerging capital markets: Evidence from Chinese Listed companies" Ph-D thesis. Business School. Faculty of Humanity and Social Science New Castle University.

- Chebaane, S. and H. B. Othman, 2014," The Impact of IFRS Adoption on Value Relevance of Earnings and Book Value of Equity: the Case of Emerging Markets in African and Asian Regions", Procedia - Social and Behavioral Sciences, No. 145, pp. $70-80$.

- Chen, Charles J.P., Chen Shimin, and Su Xijia (1999) “Is Accounting Information Value-Relevant in the Emerging Chinese Market” Journal of International, Accounting, Auditing and Taxation 10(1): 1-22

- Chen, C. J. P. and Su, S. C. (2001) "Is accounting information value relevant in the emerging Chinese Stock Market?” Journal of International, Accounting, Auditing and Taxation” 10, (1), 1-22

- Collins, D.W., Maydew, E. L. and Weiss, I. S. (1997) “ Changes in value relevance of Earnings and Book values Over Past Forth Years"Journal of Accounting and economics, 24 (1):39-68

- Cuozza, B., Dumay J., Palmaccio, M and Loomabardi, R. (2017) "Intellectuaal Capital Disclosure: a structured literature review" Journal of Intellectual Capital. Vol.18 No. 1 pp. $9-28$ 
- Dahmash, F., Durand R. and Watson J. (2009)" The value relevance and reliability of reported intangibles and identifiable intangible assets" The British Accounting Review. Vol.41 no. 1, pp.120-137

- Elshandidy, Tamer (2014) "Value relevance of accounting information: Evidence from an emerging market" Advances in Accounting, incorporating Advances in International Accounting 30; pp. 176-186 Available at Science Direct

- Fan, J.P. H. and Wong. T. J. (2002) "Corporate ownership structure and the Informativeness of accounting earnings in East Asian" Journal of Accounting and Economics, 33 (3): 401-425

- Feltham, G.A. and Ohlson, J.A. (1995), "Valuation and clean surplus accounting for operating and financial activities”, Contemporary Accounting Research, Vol. 11 No. 2, pp. 689-732.

- Francis, Jennifer and Katherine Schipper (1999) "Have financial statements lost their relevance" Journal of Accounting Research, 37 (02), 319-352 http:// dx.doi.org/10.230/2491412

- Ghaharmanizady, Mohammad and Mehdi Behname (2013) "Intangible Assets Value Relevance; Metals Industry of Tehran Stock Exchange Case Study" Technical Journal of Engineering and Applied Sciences -3-21/2759-2765 Available online at www.tjeas.com

- Giosi, Alessandro,SilviaTestarmata and Ignazio Buscema (2013)" The value relevance of Financial information in troubled waters; The Evidence of Italian Context"Ownership and Control 11, (1), 62-67

- Goldfinger, C. (1997) "Intangible economy and its Implications for statistics and statisticians" International Statistical review, 191-220

- Gong, J. J. and S. I. Wang, (2016),"Changes in the Value Relevance of Research and Development Expenses after IFRS Adoption", Advances in Accounting, Vol. 35, pp. 4961.

- Green, J. P. Stark, A.W. and Thomas H. M. (1996) “UK evidence on the market valuation of R\&D expenditures" Journal of Business Finance and Accounting 23, 191216 
- Gunathilaka, A.G. Chandana (2014) "Financial Distress Prediction: A comparative Study of Solvency Test and Z-Score Models with Reference to Sri Lanka" Research Gate. Available on line at http://www.research gate.net/publication/278021017

- Hasso, Tim (2013) "Family Ownership and the Value Relevance of Accounting Information" Thesis of Doctor of Philosophy, Scholl of Business. Bond University, Australia

- Holderness, Clifford G, (2010) “ Block holders are more common in the United States than you might think"Journal of Applied Corporate Finance, Volume 22, No.4

- Jensen, M.J. and W. Meckling. (1976) "Theory of the firm: Managerial behavior, agency costs and ownership structure" Journal of Financial Economics, 28: 51-82.

- Ji, Xu Dong and Wei Lu (2014) “ The value relevance and reliability of intangible assets: Evidence from Australia before and after adopting IFRS" Asian Review of Accounting Vol. 22.No. 3, pp. 182-216

- Kallupar, S and Kwan, S.Y.S. (2004) "The value relevance and reliability of brand assets recognized by UK firms" The accounting Review. Vol.79 No. 1, pp.151-172

- Kang, Helen H. and Sidney J. Gray (2011) "Reporting Intangible Assets: Voluntary Disclosure Practices of top emerging market companies" The International Journal of Accounting.46, Issue 4; 402-423.

- Kimounche, Bilal and Rouabhi, Abdelnacer (2016) "The impact of intangibles on the value relevance of accounting information: Evidence from French Companies" Intangible Capital pp.506-529

- Leaven, L. and Levine R. (2008) "Complex ownership structures and corporate valuation" Review of financial studies, pp.579-604

- Lev B. (2001) “ Intangibles: Management, measurement and reporting” Brooking institution Press Washington DC

- Lev, B. (1989). On the usefulness of earnings and earnings research: Lessons and directions from two decades of empirical research. Journal Accounting Research, 27, 153-192.http://dx.doi.org/10.2307/2491070

- Lev, B., and Zaraowin P. (1999) "The boundaries of financial reporting and how to extend them" Journal of Accounting Research, 353-385 
- Lim, Soon Hong (2012)" Ownership Structure and concentration and the Timeliness of Corporate earnings; Malaysia Evidence" Master thesis, School of Economics and Finance Faculty of Business. Queensland University of Technology Brisbane Australia

- Martinez, C. R. 2015,"Impact of the IFRS Intensive Firms' Accounting Reports: Empirical Evidence from Latin America", Available at: http://ssrn.com/abstract=2611304.

- Miller, D. Le Breton-Miller, I., Scholnick, B., and Montreal H. (2008) "Stewardship vs Stagnation: An Empirical comparison of small family and non small family businesses“، Journal of Management Studies, 45 (1), 51-78

- Morricone, Serena and Oriani, Raffaele and Sobrero, Maurizio (2009)" The Value relevance of intangibles and the Mandatory Adoption of IFRS" Available at ssrn: http://ssrn.com/abstract $=1600725$

- Okafor, Oliver N., Mark Anderson, Hussein Warsame (2016) “ IFRS and value relevance: evidence based on Canadian Adoption" International Journal of Management and Finance, Vol.12 Issue; 2 pp.136-160

- Ohlson, J.A. (1995)" Earnings, book values and dividends in security valuation" Contemporary Accounting Research, 11 (2): 661-687

- Omoye, AladeSule (2013) "Determinants of intangibles assets disclosure in annual report: Evidence from Nigerian quoted companies" International Journal of Asian Social Science, 3 (5), 1152-1165

- Pervan, Ivika and MarijanaBartulovic(2013) "Determinants of value relevance of accounting information: comparative analysis for listed companies from South East Europe"Recent Researches in Business and Economics

- Ragab, Aiman A. and Mohammed M. Omran (2006) "Accounting Information, value relevance, and investors' behavior in the Egyptian Equity market" Review of Accounting and Finance, Vol. 5 Issue 3, pp.279-297

- Salehi, Mehrdad, Hashem Valipour and javadiMoradi (2013) "Moderating effect on the relationship between a company's life cycle and the relevance of accounting practices of intangible assets" Asian Economic and Financial Review, 3 (8);1096-1109 
- Strik, Marco (2011) "The implications of dispersed ownership structure vs. large shareholders on company performance in the US" Master thesis

- Thomsen, S. and Pederson, T. (2000) Ownership Structure and value of largest European Firms: the Importance of ownership identity" Strategic Management Journal, 21(6), 689-705

- Tsoligkas, F. and I. Tsalavoutas (2011) "The value relevance of R\&D in the UK after IFRS mandatory implementation" Applied Financial Economics, No. 21, pp.957-967

- Wang (2006) "Founding Family Ownership and Earnings Quality" Journal of Accounting Research, 44(3): 619-656

- Zhang, Meiyi (2012) “ Board structure, ownership concentration and intellectual capital” Master thesis at Victory University of Wellington 


\section{Appendix}

List of Listed companies included in the research study

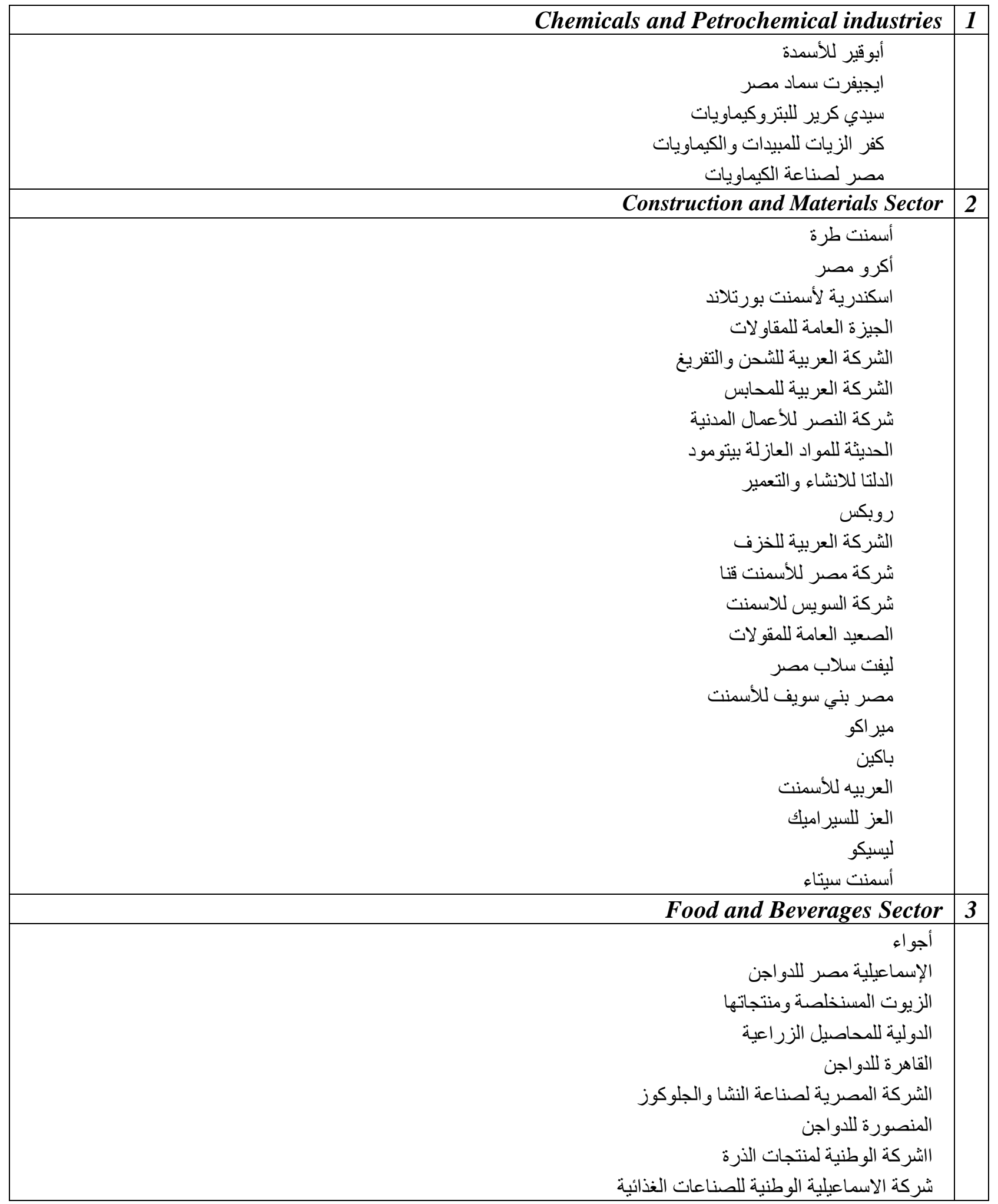




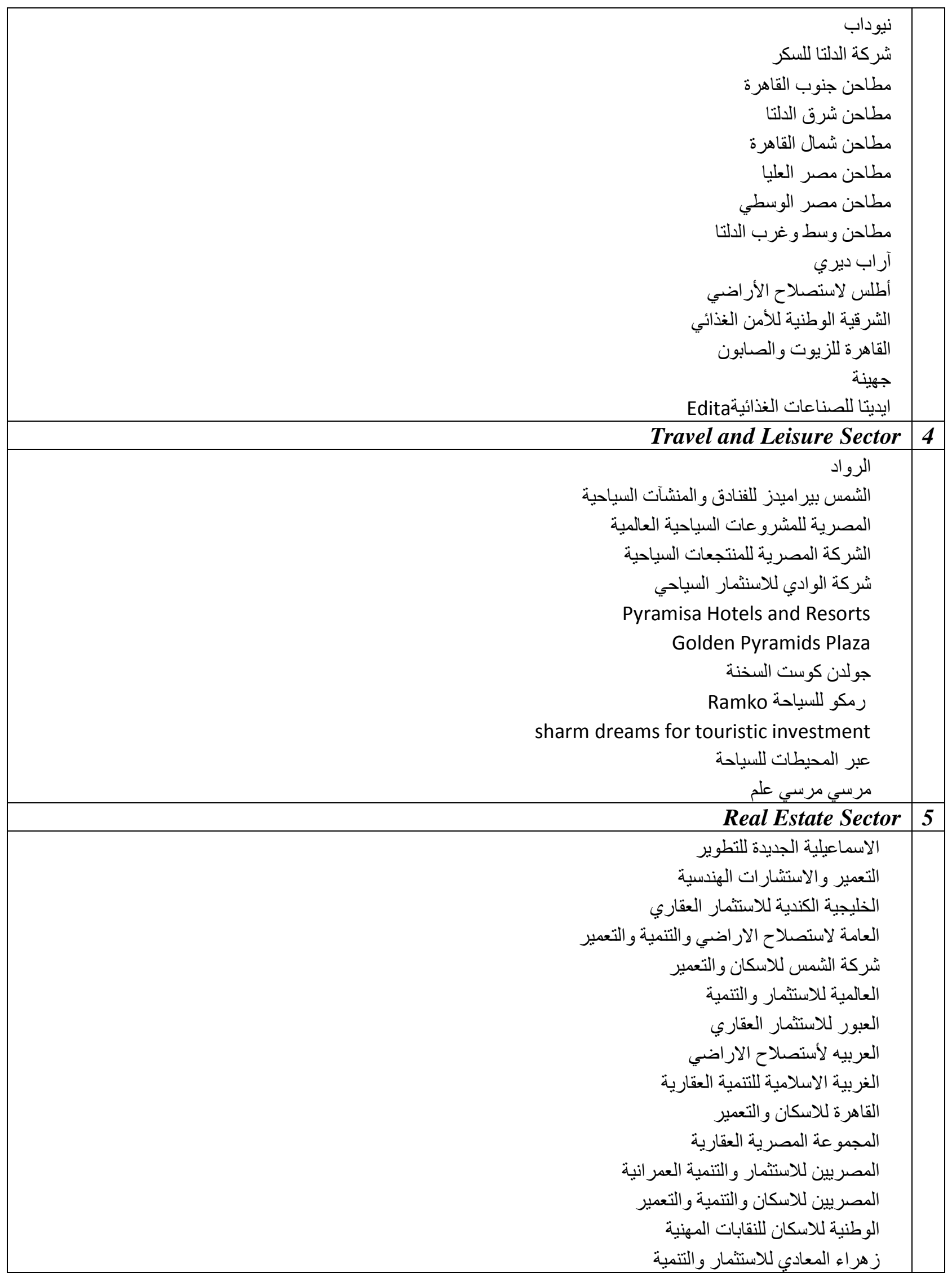




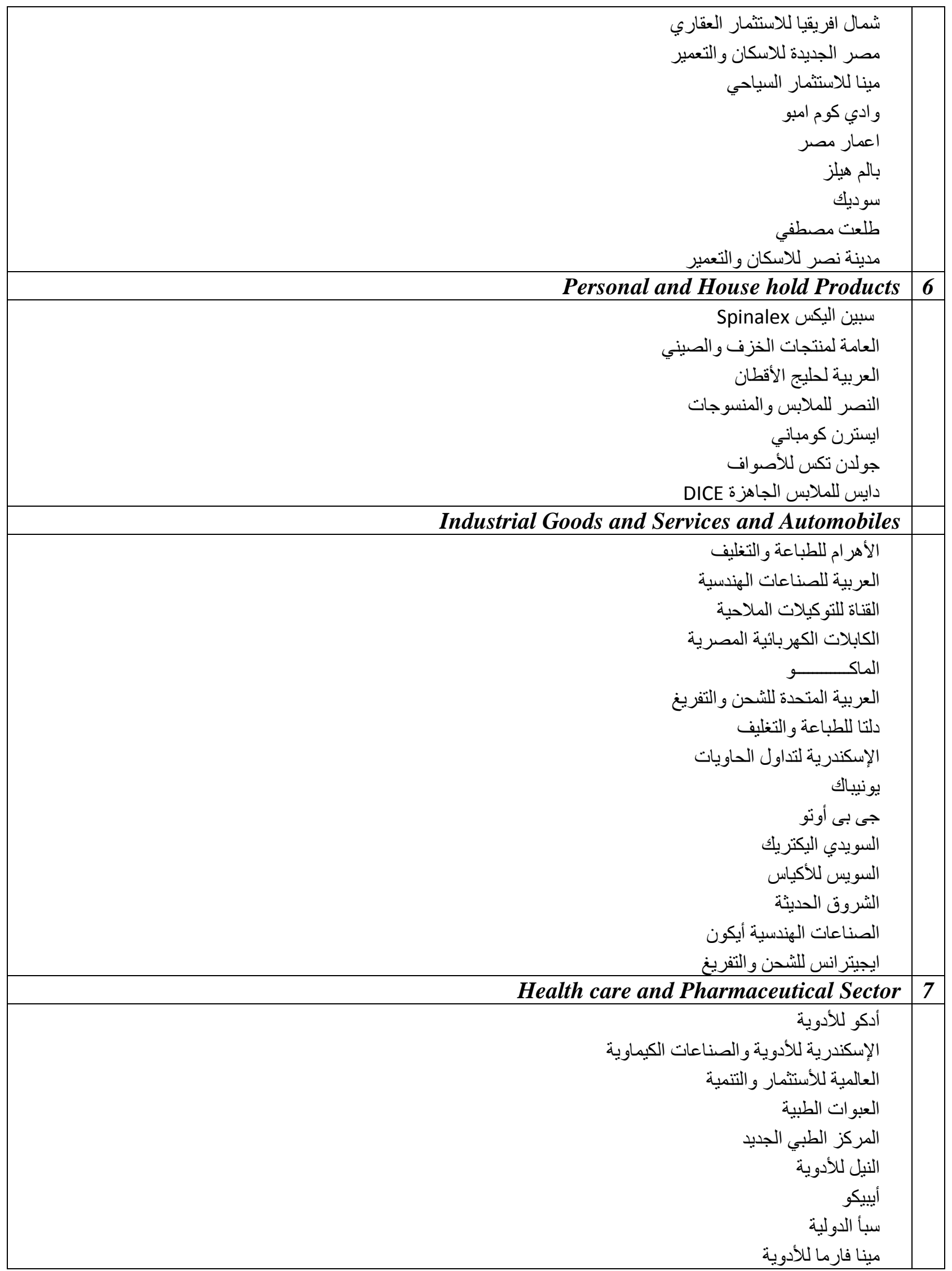




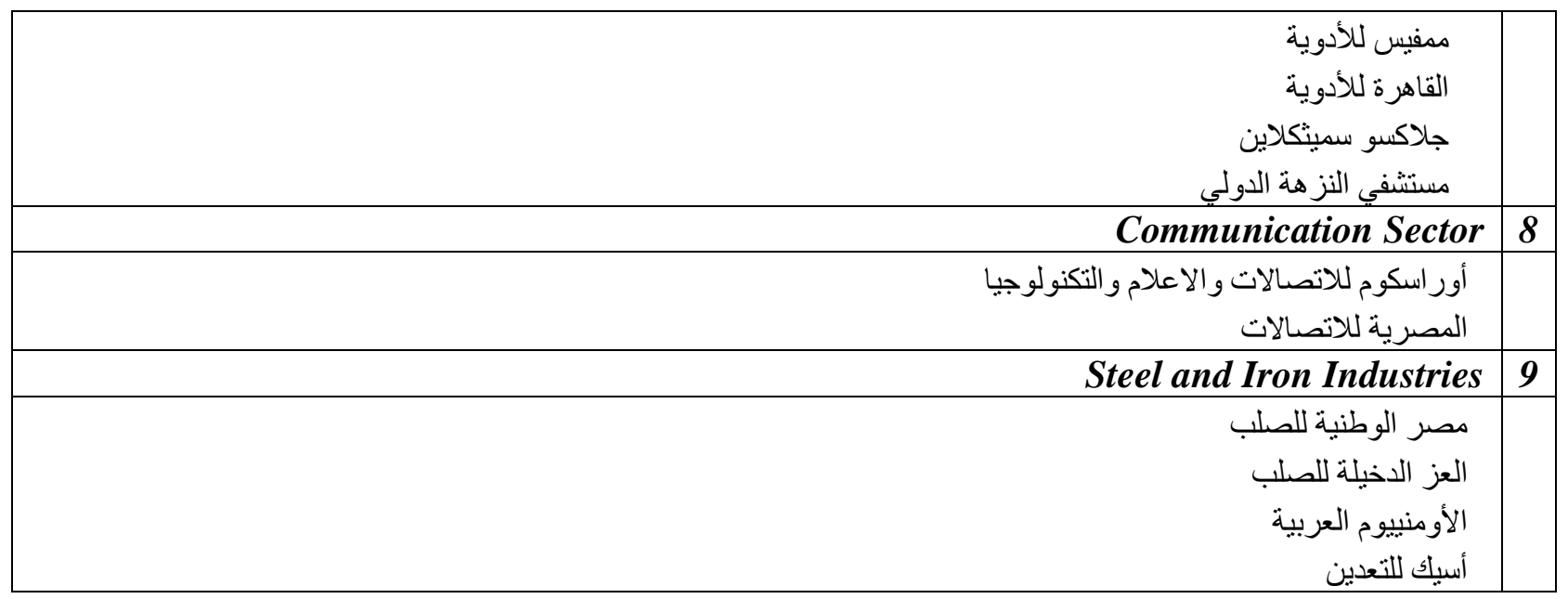


